\section{FEASIBILITY STUDY OF NET-ZERO ENERGY RESIDENTIAL BUILDINGS IN HOT AND HUMID CLIMATES: A CASE STUDY OF IRAN}

\author{
Amin Mohammadi*, Seyed Mohammad Mousavi \\ Department of Architectural Engineering, Faculty of Art and \\ Architecture, Persian Gulf University, 75169, Bushehr, Iran
}

Article history

Received

16 September 2021

Received in revised form

16 December 2021

Accepted

11 January 2022

Published Online

21 February 2022

*Corresponding author aminmohammadi@pgu.ac.ir

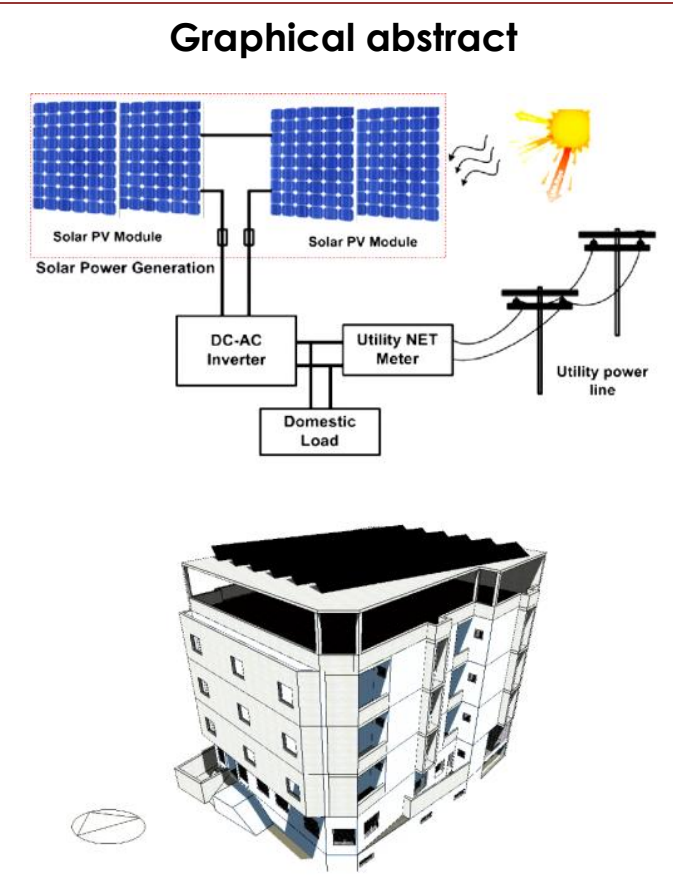

\begin{abstract}
The use of solar energy in buildings is a good alternative to fossil fuels considering the geographical location of Iran. The present research evaluated the feasibility of net-zero energy residential buildings in southern Iran using a distinct framework. To this end, a low-energy and simulated model of a multi-family residential building as the dominant typology in Bushehr city equipped with combined (active and passive) solutions were used in Design Builder software for optimizing energy consumption. Annual electricity consumption of this simulated model was reduced by $48 \%$ using very low power density appliances and an Air Source Heat Pump (ASHP) water heater with an Energy Star label to supply hot water. Then, a grid-connected PV system with a capacity of $29 \mathrm{~kW}$ was used to provide the annual electricity demand. The results indicate that this system annually generates $52 \mathrm{MWh}$ of electricity that not only covers the annual electricity demand but also sends 5.8 MWh of additional electricity to the grid. The Economic analysis indicates that the payback period in this project will be very long. Therefore, achieving NZEBs in southern Iran is technically feasible but, from the economic point of view, it depends on the provision of the economic infrastructures.

Keywords: Feasibility study, hot and humid climate, Persian Gulf region, Netzero energy building, Photovoltaic system
\end{abstract}

(C) 2022 Penerbit UTM Press. All rights reserved

\subsection{INTRODUCTION}

Global energy demand increased by almost $35 \%$ from 1990 to 2018 because of the fast growth of population and urban development in developing nations. It seems that this increase will continue between 5 and $10 \%$ every 5 years until 2035 [1-3]. In Iran, 36.25\% of energy consumption is in building construction and operation, and the buildings are responsible for emitting $25 \%$ of the greenhouse gases emitted because of using gas and oil products [4]. According to a report from the statistical center of Iran in 2014 [5], Three provinces including Bushehr, Khosestan, and Hormozgan in the South-West part of this country with hot and humid climate have experienced the highest electricity demand and $\mathrm{CO}_{2}$ emission for residential buildings and severe climate conditions during the past decades compared to the other parts of this country. Given the critical situations in this region of Iran, a comprehensive techno-economic and environmental feasibility study of suitable alternatives to fossil fuels seem urgent. Solar energy is a practical alternative to meet the energy needs of countries. In this regard, green and energy-efficient buildings like zero energy buildings (ZEBs) have fascinated governments [4]. Nowadays, Net Zero Energy Buildings (NZEBs) are known as a creative theory in designing research related to building technology, HVAC 
systems, and as a practical technique in combating energy shortages and environmental pollution worldwide [5]. According to a general description of NZEB by the U.S. Department of Energy [6], a commercial or residential NZEB is a structure whose energy demands are dramatically reduced, and the balance of its energy needs could be provided through renewable techniques.

A review of the studies on NZEBs [7-11] shows that these buildings are developing in different countries. In some countries like South Korea, China, and the United States [12-17], NZEBs have been the subject of research in various parts of these countries. Moreover, these buildings have attracted the attention of researchers in temperate and Mediterranean climates in Egypt, Italy, Cyprus, Spain, and France [18-23]. However, many studies on this subject, during the past ten years, can be seen in the hot and humid areas with long sunny hours and intensive solar radiation in various countries, including China, the United States, Singapore, Egypt, Panama, Australia, Saudi Arabia, Thailand, and India [2, 5, 24-38], as shown in Table 1.

Table 1 Relevant studies in the past 10 years in the hot and humid regions

\begin{tabular}{|c|c|c|c|c|c|c|c|c|c|}
\hline \multirow[t]{2}{*}{ Authors } & \multirow{2}{*}{$\begin{array}{l}\text { Building Type } \\
\text { Location }\end{array}$} & \multirow{2}{*}{$\begin{array}{l}\text { Research } \\
\text { Method }\end{array}$} & \multicolumn{3}{|c|}{ Energy Efficiency Measures } & \multicolumn{4}{|c|}{ Main Objectives in NZEBs Design } \\
\hline & & & Passive & Active & Renewable & ES & EP & $\mathrm{TCl}$ & CCR \\
\hline $\begin{array}{c}\text { Ng, P.K. and N. } \\
\text { Mithraratne (2014) }\end{array}$ & $\begin{array}{l}\text { Commercial } \\
\text { Singapore }\end{array}$ & S & $x$ & $x$ & $\sqrt{ }$ & NA & NA & NA & NA \\
\hline $\begin{array}{c}\text { Deng, S., et al. } \\
(2011)\end{array}$ & $\begin{array}{l}\text { Residential } \\
\text { China }\end{array}$ & S & $\checkmark$ & $\sqrt{ }$ & $\checkmark$ & NA & $\begin{array}{l}94-152 \\
k w h m^{2}\end{array}$ & $\begin{array}{c}\text { Temperature } \\
\text { Analysis }\end{array}$ & NA \\
\hline $\begin{array}{l}\text { Abd-Ur-Rehman, } \\
\text { H.M., et al. (2018) }\end{array}$ & $\begin{array}{l}\text { Residential } \\
\text { Saudi Arabia }\end{array}$ & S & $\sqrt{ }$ & $x$ & $\sqrt{ }$ & $\begin{array}{c}76 \% \\
\text { DHW, 56\% } \\
\text { cooling, } \\
37 \% \\
\text { heating, } \\
46 \% \\
\text { lighting, } \\
27 \% \\
\text { appliance }\end{array}$ & $\begin{array}{l}3247 \text { kwh } \\
\text { surplus } \\
\text { electricity }\end{array}$ & NA & $\begin{array}{c}13.3 \\
\text { years } \\
\text { payback } \\
\text { period }\end{array}$ \\
\hline $\begin{array}{l}\text { Attia, S. and S. } \\
\text { Carlucci (2015) }\end{array}$ & $\begin{array}{l}\text { Residential } \\
\text { Egypt }\end{array}$ & S & $\sqrt{ }$ & $\sqrt{ }$ & $\checkmark$ & $\begin{array}{l}10-18 \% \\
\text { cooling } \\
\text { loads }\end{array}$ & NA & $\begin{array}{l}\text { Adaptive } \\
\text { Thermal } \\
\text { Comfort } \\
\text { Model }\end{array}$ & NA \\
\hline $\begin{array}{c}\text { Boonyaputthipong, } \\
\text { C. (2019) }\end{array}$ & $\begin{array}{l}\text { Educational } \\
\text { Thailand }\end{array}$ & $E$ & $\sqrt{ }$ & $\sqrt{ }$ & $\sqrt{ }$ & $30-40 \%$ & $\begin{array}{c}26 \\
\text { MWhyear }\end{array}$ & NA & NA \\
\hline $\begin{array}{l}\text { Hoque, S. and N. } \\
\text { lqbal (2015) }\end{array}$ & $\begin{array}{l}\text { Residential } \\
\text { Panama }\end{array}$ & S & $\sqrt{ }$ & $\sqrt{ }$ & $\sqrt{ }$ & NA & $2.46 \mathrm{MWh}$ & NA & NA \\
\hline Hu, M. (2019) & $\begin{array}{c}\text { Educational } \\
\text { USA }\end{array}$ & S & $\sqrt{ }$ & $\sqrt{ }$ & $\sqrt{ }$ & $80 \%$ & NA & NA & $\begin{array}{l}90 \% \\
\text { reduction } \\
\text { in LCC }\end{array}$ \\
\hline $\begin{array}{c}\text { Klingenberg, K., M. } \\
\text { Kernagis, and M. } \\
\text { Knezovich (2016) }\end{array}$ & $\begin{array}{l}\text { Residential } \\
\text { North America }\end{array}$ & S & $\sqrt{ }$ & $\sqrt{ }$ & $\checkmark$ & NA & NA & NA & NA \\
\hline $\begin{array}{l}\text { Kurdi, Y., et al. } \\
(2016)\end{array}$ & $\begin{array}{l}\text { Residential } \\
\text { USA }\end{array}$ & ES & $\sqrt{ }$ & $\sqrt{ }$ & $\sqrt{ }$ & $42 \%$ & NA & NA & $\begin{array}{c}83 \% \\
\text { saving in } \\
\text { electricity } \\
\text { cost }\end{array}$ \\
\hline $\begin{array}{l}\text { Kwan, Y. and L. } \\
\text { Guan (2015) }\end{array}$ & $\begin{array}{l}\text { Residential } \\
\text { Australia }\end{array}$ & ES & $\sqrt{ }$ & $\sqrt{ }$ & $\sqrt{ }$ & $66 \%$ & $\begin{array}{l}7.2 \mathrm{MWh} \\
\text { Year }\end{array}$ & NA & $\begin{array}{l}10 \text { Years } \\
\text { Payback } \\
\text { Period }\end{array}$ \\
\hline $\begin{array}{l}\text { Lou, S., et al. } \\
(2017)\end{array}$ & $\begin{array}{l}\text { Educational } \\
\text { Hong Kong }\end{array}$ & S & $\sqrt{ }$ & $\sqrt{ }$ & $\sqrt{ }$ & NA & $\begin{array}{l}408 \mathrm{MWh} \\
\text { Year }\end{array}$ & NA & NA \\
\hline Lu, Y., et al. (2017) & $\begin{array}{l}\text { Office Hong } \\
\text { Kong }\end{array}$ & S & $\sqrt{ }$ & $\checkmark$ & $\sqrt{ }$ & NA & NA & NA & NA \\
\hline $\begin{array}{l}\text { Ng, T.S.K., et al. } \\
(2016)\end{array}$ & $\begin{array}{l}\text { Office Hong } \\
\text { Kong }\end{array}$ & S & $\sqrt{ }$ & $\sqrt{ }$ & $\sqrt{ }$ & $45 \%$ & $\begin{array}{l}87 \mathrm{MWh} \\
\text { Year }\end{array}$ & NA & NA \\
\hline Russell, S.R. (2012) & $\begin{array}{l}\text { Residential } \\
\text { USA }\end{array}$ & $E$ & $\sqrt{ }$ & $\sqrt{ }$ & $\sqrt{ }$ & NA & NA & NA & NA \\
\hline $\begin{array}{c}\text { Shin, M., et al. } \\
\text { (2019) }\end{array}$ & Office USA & ES & $\sqrt{ }$ & $\sqrt{ }$ & $\sqrt{ }$ & $37-45 \%$ & NA & NA & NA \\
\hline $\begin{array}{c}\text { Sudhakar, K., M. } \\
\text { Winderl, and S.S. } \\
\text { Priya (2019) }\end{array}$ & Office India & ES & $\sqrt{ }$ & $\sqrt{ }$ & $\sqrt{ }$ & NA & NA & NA & NA \\
\hline $\begin{array}{l}\text { To, C., J. Li, and M. } \\
\text { Kam (2017) }\end{array}$ & $\begin{array}{l}\text { Office- } \\
\text { Residential } \\
\text { Hong Kong }\end{array}$ & ES & $\sqrt{ }$ & $\sqrt{ }$ & $\sqrt{ }$ & $45 \%$ & $\begin{array}{c}87 \\
\text { MWhyear- } \\
\text { 100MWh } \\
\text { surplus } \\
\text { electricity }\end{array}$ & NA & NA \\
\hline Current study & $\begin{array}{l}\text { Residential- } \\
\text { Iran }\end{array}$ & S & $\checkmark$ & $\sqrt{ }$ & $\sqrt{ }$ & $48 \%$ & $\begin{array}{c}52 \\
\text { MWh/year- } \\
\text { 33.6 MWh } \\
\text { Surplus } \\
\text { electricity }\end{array}$ & $\begin{array}{l}\text { PMV and PPD } \\
\text { improvement }\end{array}$ & $\begin{array}{l}6 \text { Years } \\
\text { Payback } \\
\text { Period- } 73 \\
\% \mathrm{CO}_{2} \\
\text { reduction }\end{array}$ \\
\hline
\end{tabular}


In the last decade, the NZEBs concept had been of high interest in Iran, as well. In a feasibility study of NZEBs, Rezaee et al. [39] offered a systematic framework suitable for architectural design phases. They used a well-constructed method for identifying house typology in Shiraz, Iran, and developed a parametric model that generated many ways for the evaluation of electricity generation and energy demand in buildings. Their results showed that by modifying the power density of lighting systems and building components, achieving an NZEB is quite feasible, and lighting loads, infiltration, and wall insulation are the most important parameters that affect the energy performance in this region. To optimize the energy use of an NZE office building by increasing the thermal comfort of the occupants in Zahedan, Iran, Mahdavi Adeli et al. [40] compared the important parameters of internal thermal comfort conditions using optimization and Computational Fluid Dynamics (CFD). Vaghefpour et al. [41] have made suggestions for replacing solar energy to provide the required energy for lighting, cooling, and heating in the buildings in Iran. Some of the results of the study are the development of the economy and job opportunities parallel to the development of solar energy. Moreover, the authors conclude that because of the high cost of developing solar energy, the demand for its use is low. So, they suggested considering the use of appropriate subsidies in this area. In the work of Eshraghi et al. [4], a typical type of detached building in Tehran with a relatively warm climate was chosen as an NZEB case study. Most of the building's heating and cooling loads are provided by using Trombe walls, thermal mass, and roller shading as the main inactive strategies. Also, a solar absorption heat pump was used to provide the cooling and heating needs of the building. Photovoltaic panels were also used to generate and store electricity in the battery, and additional electricity was sent to the grid. Sensitivity analysis in this study indicated that an initial investment in solar energy could be compensated only with the real energy price and low-interest rate (less than 5\%). In another study conducted in Mashhad, Iran's secondlargest city [42], 15 solar thermal collectors were used instead of natural gas to preheat the radiators' water cycle to heat the spaces and provide hot water used in a residential apartment. Then, the authors discussed the issues such as the heat energy from these collectors and replacing it with natural gas for the feasibility of an NZEB, the rate of reduction in the use of natural gas, the payback period in solar collectors, and the rate of decrease in $\mathrm{CO}_{2}$ emissions. In another study in Isfahan [43], a city with a hot and dry climate, effective factors in NZEB design including building form, climatic characteristics, and materials used in library and field methods were examined.

The literature review shows that in the feasibility studies of NZEBs in the hot and humid regions in the past 10 years, three important parameters including thermal comfort improvement, energysaving/production, and Cost/Carbon reduction have not been analyzed and discussed completely as the main objectives in NZEBs design. Besides, the feasibility of NZEBs has currently not been investigated with a distinct method in the South-West region of Iran with a hot and humid climate. To address these research gaps, a novel framework that has Two steps was provided. In the first step, the solar radiation map and the PV power potential map of the region are reviewed, the prototype buildings are identified, and the base case model(s) are selected in a library study. In the second step, after modeling and simulation of the base case model(s) and reviewing the preliminary results, we choose the appropriate Energy Conservation Measures (ECMs) including passive, active, and renewable strategies, and utilize them in the base case model(s) to reduce the energy demand as much as possible and to balance the energy needs to achieve an NZEB. Finally, the simulation results of the NZEB are categorized and analyzed. If the results meet the main objectives, the final decision is made about the feasibility study. Otherwise, the process will be repeated until the desired results are achieved. In this study, we aim to design a net-zero energy model in a hot and humid region considering thermal comfort improvement, energy-saving/production, and Cost/Carbon reduction as the main objectives in NZEB design using the following framework in Figure 1. 


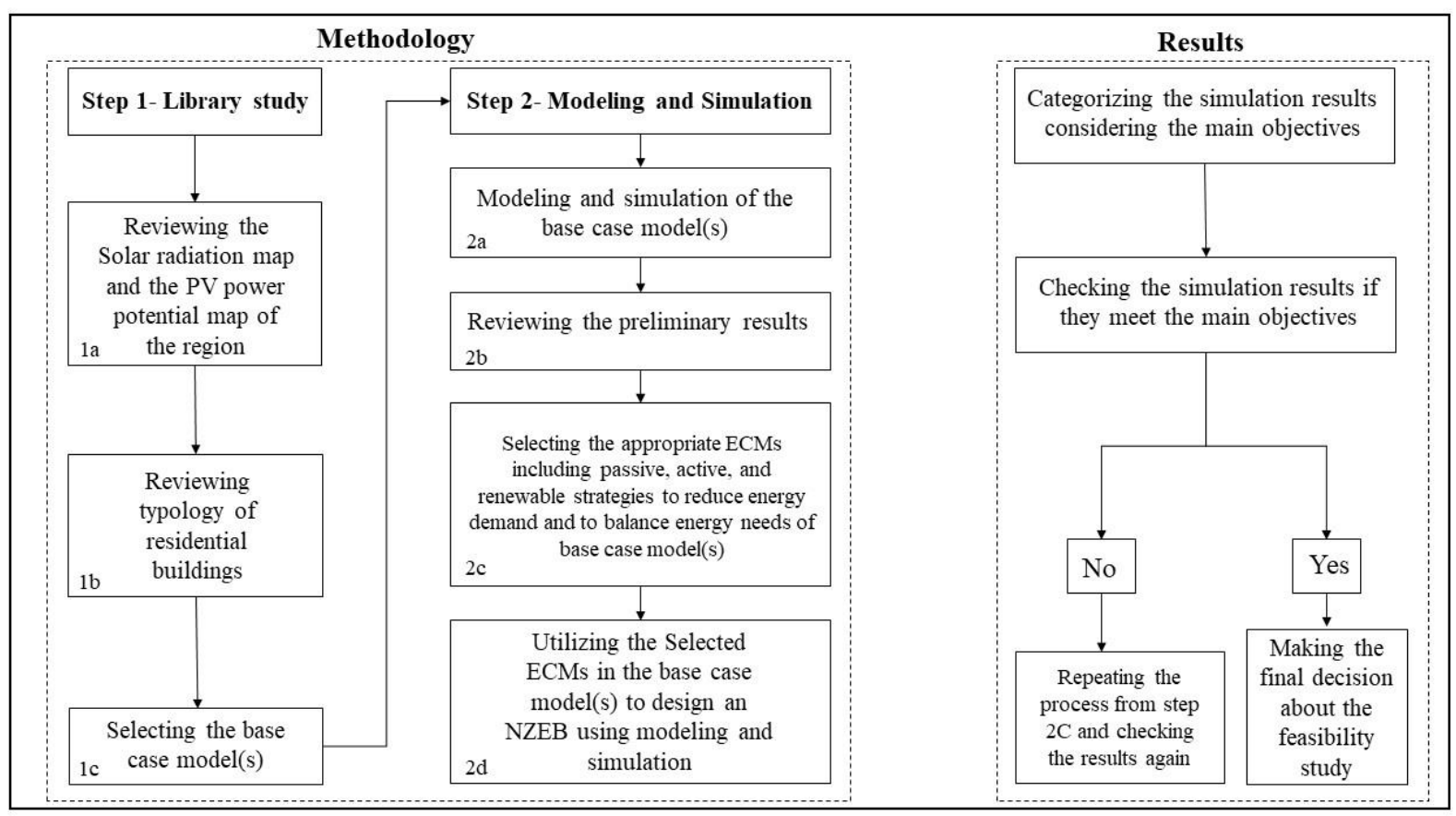

Figure 1 A research framework for the feasibility study of NZEBs in hot and humid climates

\subsection{METHODOLOGY}

The methodology of this research has been presented in this section. According to Figure 1, library study, modeling, and simulation were the main methods that were used to conduct the feasibility study of NZEBs. These methods are discussed as follow:

\subsection{Library Study}

In this part, the geographical location of the study area including Khosestan, Bushehr, and Hormozgan $(\mathrm{KBH})$ provinces has been discussed in terms of daily and annual average radiation and electricity generation. Then the average monthly temperature and relative humidity of Bushehr as the most important part of this region were presented. After that, the criteria for identifying the prototype buildings were illustrated, and finally, the base case model(s) of the study was selected and their characteristics were presented and analyzed.

\subsubsection{Overview of Geographical Location}

Iran is one of the best countries in terms of receiving solar radiation. According to Figure2, the hot and humid climates in Iran are located in the southwest corner of the country; by the Persian Gulf; and KBH provinces shape this region. These provinces with similar climates have the highest per capita electricity demand in the country, with Bushehr having the highest per capita consumption [44]. Therefore, this province can be considered as the representative of the $\mathrm{KBH}$ provinces. According to Figure 2, the daily average radiation in this region is between 2.5 and 2.6
$\mathrm{kWh} / \mathrm{m}^{2}$ and the annual average radiation is between 1826 and $2264 \mathrm{kWh} / \mathrm{m}^{2}$. Thus, there is a wide range of opportunities for using solar energy in this area.

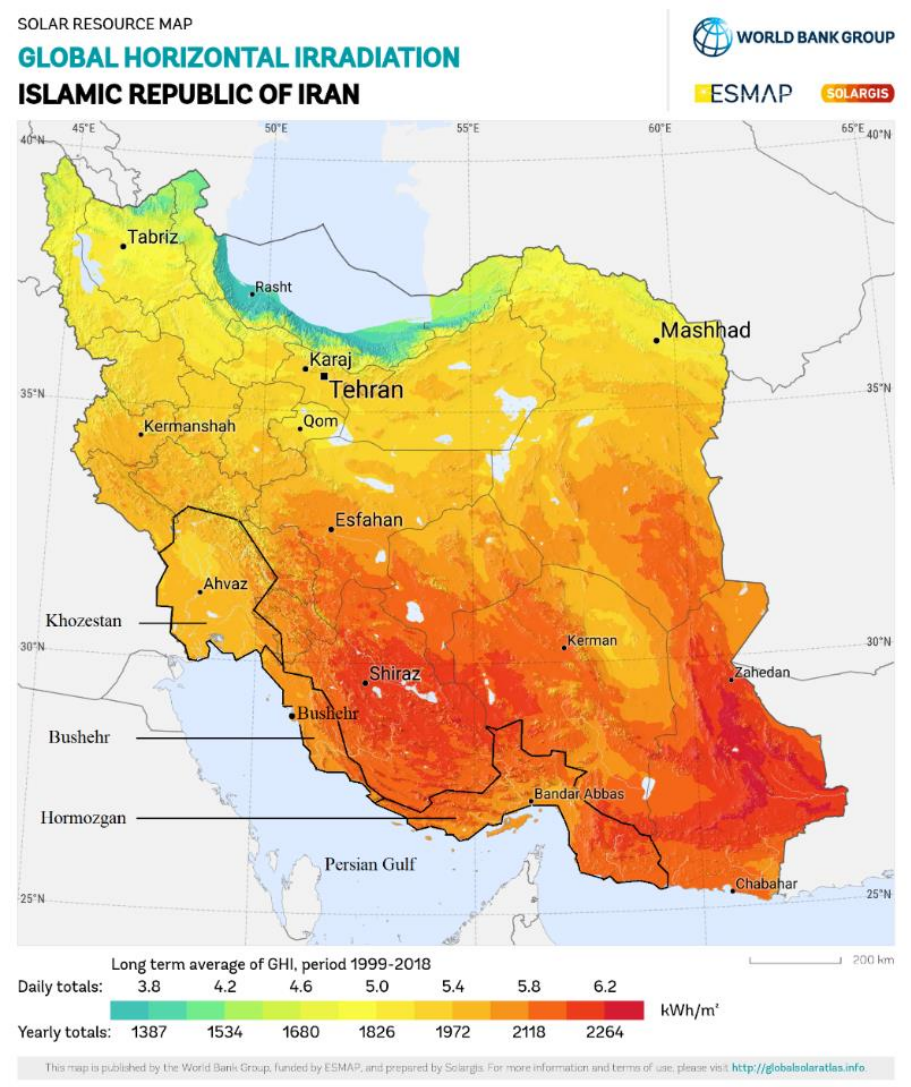

Figure 2 Solar radiation map of Iran and the location of $\mathrm{KBH}$ provinces (Source: SOLARGIS) 
In addition to the solar radiation map in different parts of Iran, the potential map of different places to use photovoltaic panels to generate electricity can be a good guide for feasibility studies. Figure 3 shows the photovoltaic power potential map of Iran. It depicts the mean daily/yearly totals of electricity production from a $1 \mathrm{~kW}$-peak grid-connected solar PV power plant considering for a recent 20-year period (1999-2018) [45]. According to this map, Bushehr has good potential for generating electricity using photovoltaic panels. In this province, the daily and annual average of electricity generation can be up to $5 \mathrm{kWh}$ per kilowatt peak and $1826 \mathrm{kWh}$ per kilowatt peak, respectively.

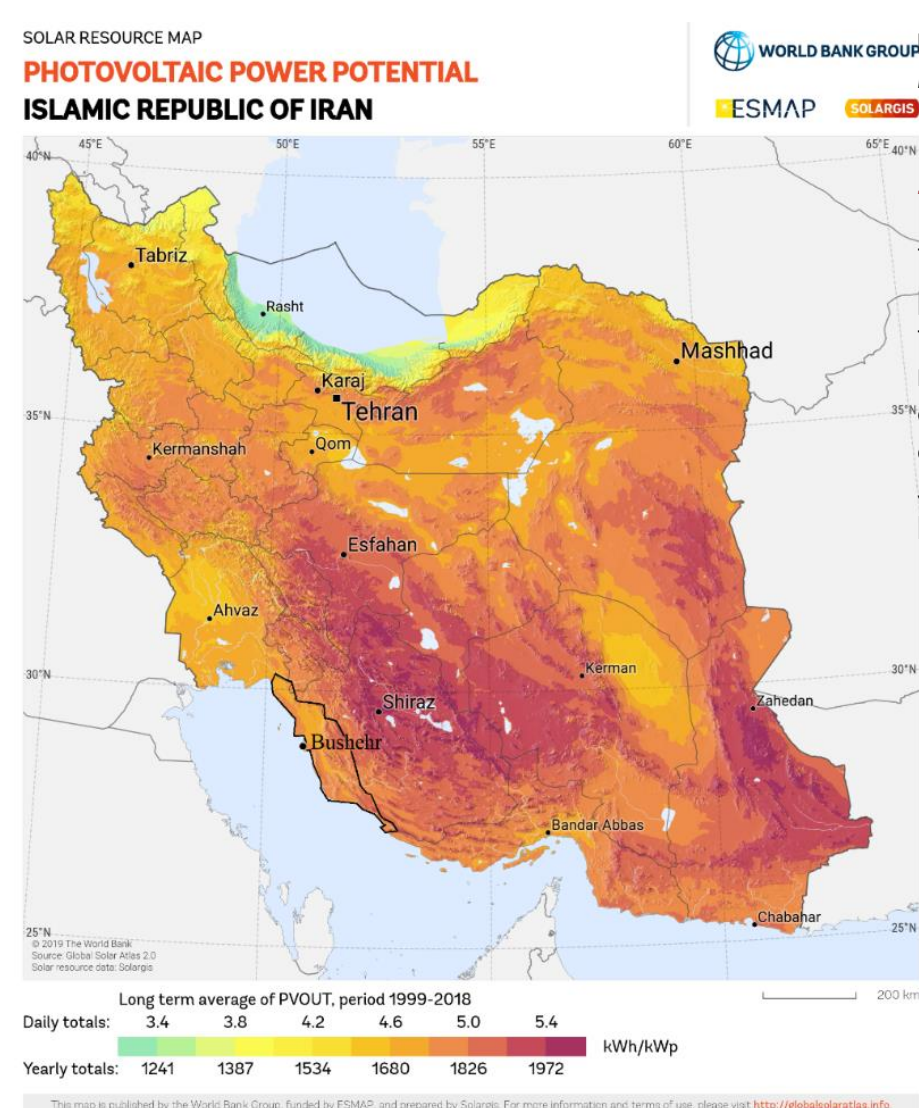

Figure 3 Photovoltaic power potential map of Iran and location of Bushehr province (Source: SOLARGIS)

Bushehr city, as the capital of Bushehr province, is located by the Persian Gulf. As shown in Figure 4, January, February, and December are relatively cold, with mean temperatures of less than $18^{\circ} \mathrm{C}$. March, April, and November are the mildest months of the year, with average temperatures ranging from 19 to $24^{\circ} \mathrm{C}$. However, in the six months of the year, from May to October, the weather is hot and humid, with a mean temperature of more than $28^{\circ} \mathrm{C}$ and a mean relative humidity of more than $59 \%$.

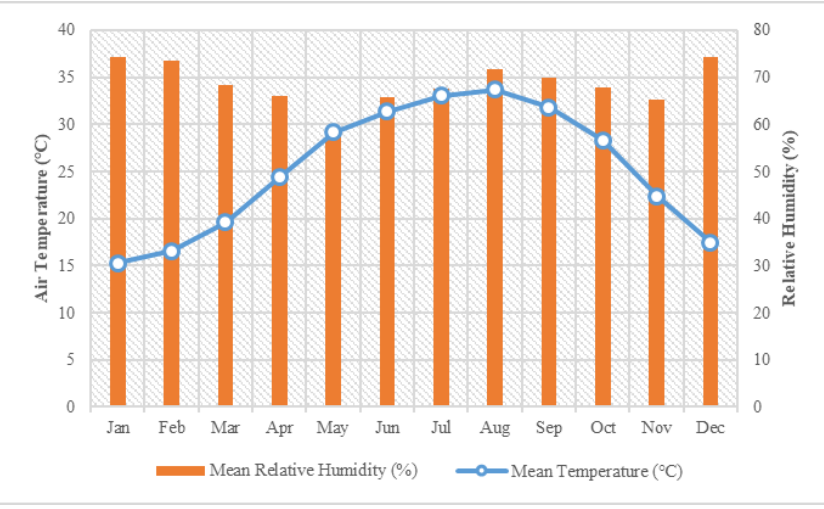

Figure 4 Average monthly air temperature and relative humidity in Bushehr from 1986-2014 (Source: Iranian Meteorological Calendar)

\subsubsection{Typology of Residential Buildings}

To identify the prototype buildings in Bushehr, the main parts of the city should be introduced. Bushehr city has two main districts as shown in Figure 5. District 1 is the most important part of the city in terms of urban "density and concentration of the urban facilities. This district has 20 residential regions according to Figure $5 \mathrm{~b}$, and RNI that is the most populated and the biggest neighborhood was selected for this study.
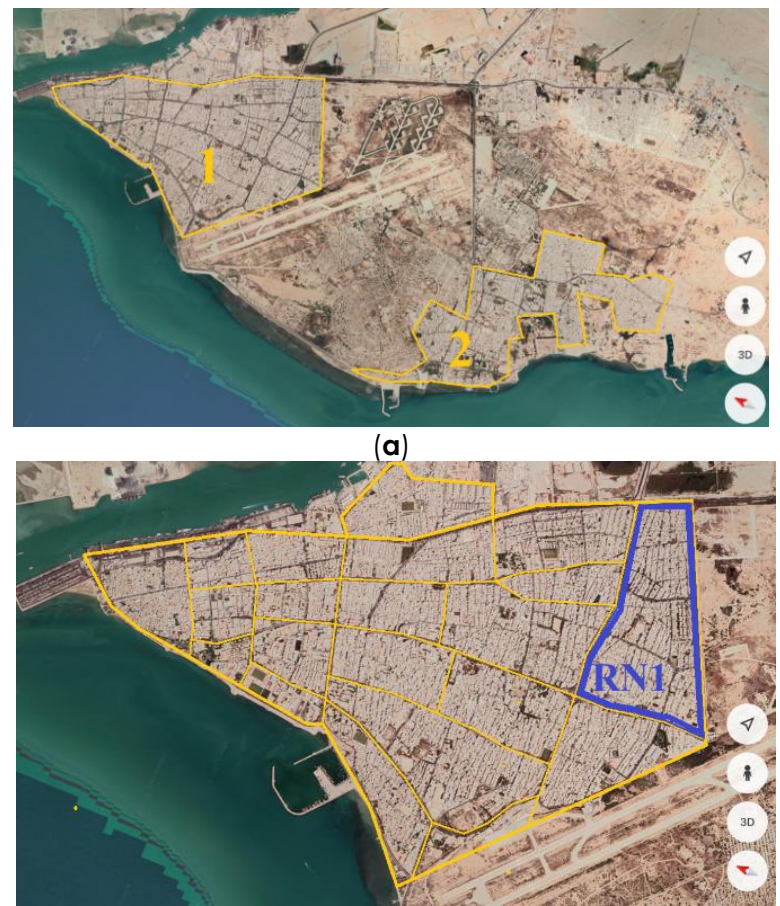

(b)

Figure 5 Bushehr city: a) district 1 and 2; b) RN1 neighborhood (Source: Google Maps)

Figure 6 shows the distribution of the newly built residential buildings in $\mathrm{RN} 1$ based on the number of floors and area. From 470 new buildings that were constructed in RN1 in recent years, 3, 4, and 5 story 
buildings with the area ranging between 219 to 1261 $\mathrm{m}^{2}, 215$ to $1843 \mathrm{~m}^{2}$, and 637 to $1705 \mathrm{~m}^{2}$ shape the dominant typology of residential buildings as shown in Figure 6.

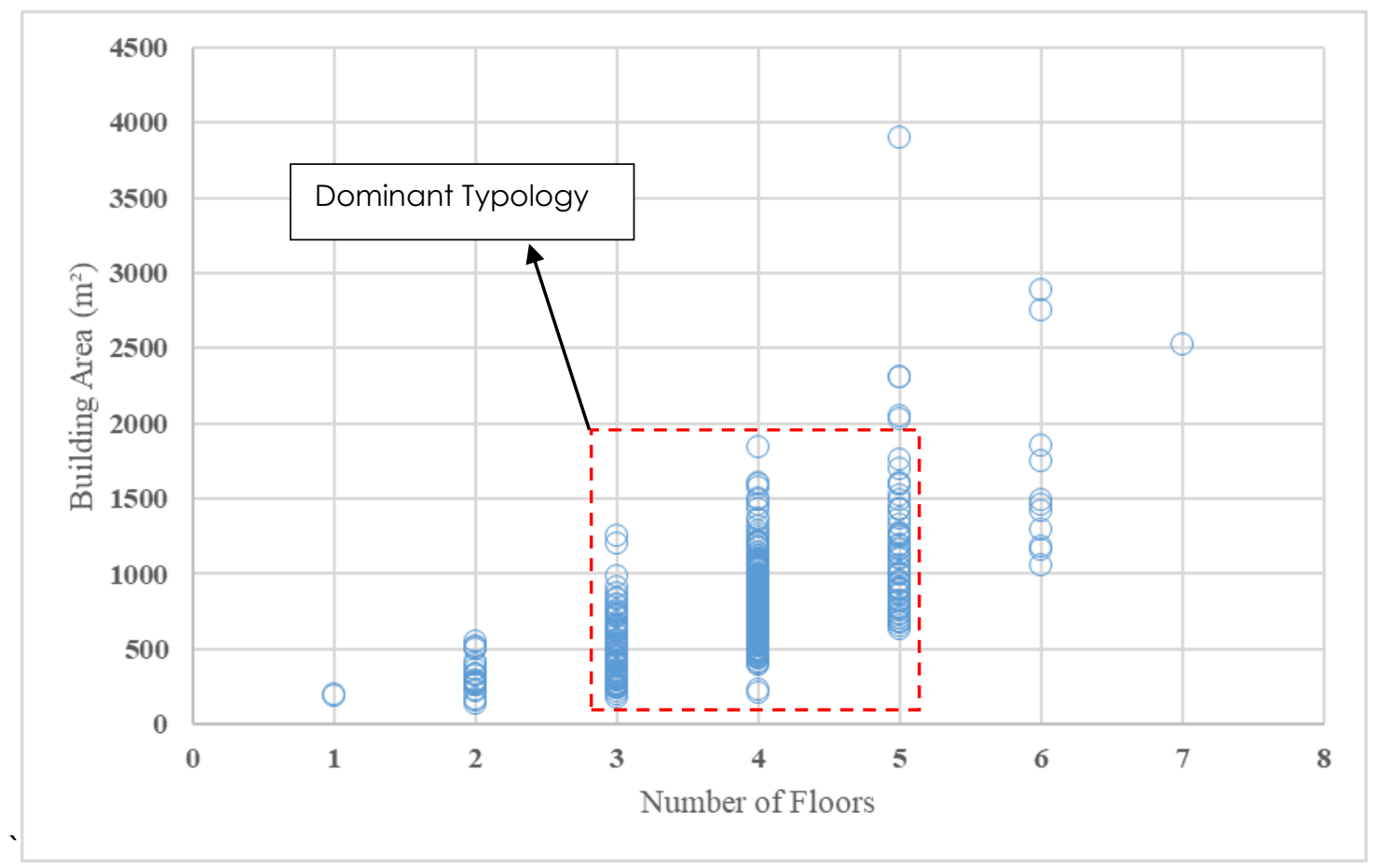

Figure 6 Distribution of 470 residential buildings in RN1 based on the number of floors and area

\subsubsection{Selecting the Base Case Model(s)}

In a neighborhood like RN1 in Figure 5b, a Multi-family residential building could have 9 different arrangements (P1-P9) as shown in Figure 7.
Located buildings in these arrangements are different in terms of thermal exchange, receiving direct/indirect solar radiation, and shading.

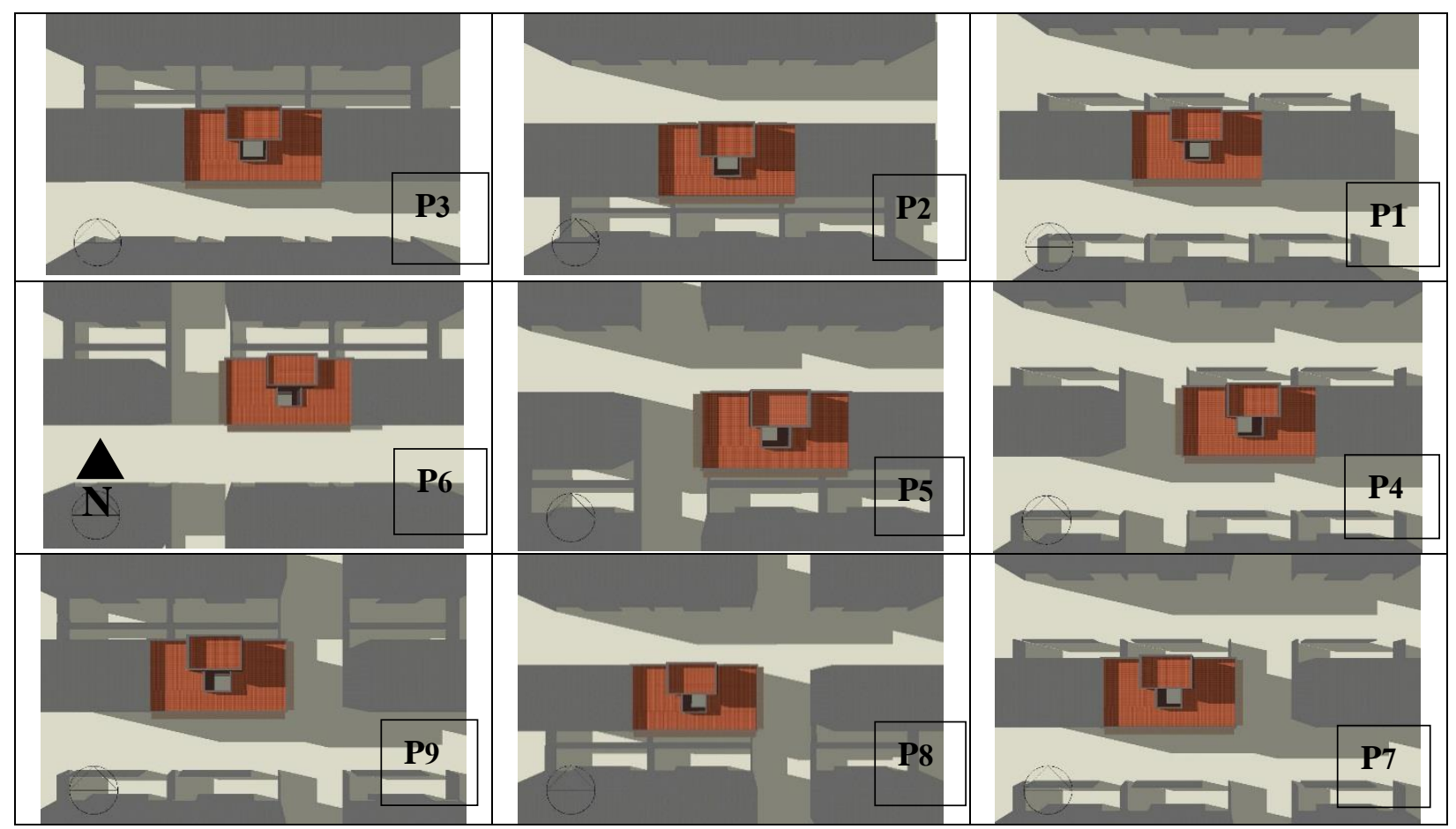

Figure 7 Different arrangements for a multi-family building in RN1 
To compare these arrangements and identify the worst-case scenario for the building energy performance, 9 typical multi-family residential buildings with an area of $630 \mathrm{~m}^{2}$ and physical characteristics and equipment shown in Table 2 were designed for these arrangements. Table 3 shows the layout for one of these models.

Table 2 Equipment and Physical characteristics for 9 typical multi-family residential buildings

\begin{tabular}{|c|c|}
\hline Equipment and Physical properties & Case Study Building \\
\hline Area & $630 \mathrm{~m}^{2}$ \\
\hline Shading in the North & Overhang/Side fins with $25 \mathrm{~cm}$ depth \\
\hline Shading in the South & Overhang with $100 \mathrm{~cm}$ depth \\
\hline Shading in the West & Vertical Shell with $100 \mathrm{~cm}$ depth \\
\hline Shading in the East & NA \\
\hline Infiltration Rate (ach) & $\mathrm{O} \mathrm{h}^{-1}$, No Fresh Air \\
\hline Cooling, seasonal CoP, and schedule & The split unit, 1.8, May to December \\
\hline Cooling Set-point & $25^{\circ} \mathrm{C}$ \\
\hline Heating, seasonal CoP, and schedule & Radiator and gas heater, 2.35, January and February \\
\hline Heating Set-point & $18^{\circ} \mathrm{C}$ \\
\hline Lighting & Suspended with the power density of $5 \mathrm{Wm}^{2}$ \\
\hline DHW, seasonal CoP & The gas-fired hot water system, 0.85 \\
\hline Thickness and material of window frame & $4 \mathrm{~cm}-$ UPVC \\
\hline Number of panes and glass type & Double pane with $10 \mathrm{~mm}$ of the air layer, Ordinary \\
\hline Heat transfer coefficient of glass & $2.05 \mathrm{Wm}^{2} \mathrm{~K}$ \\
\hline SHGC and DST of glass & 0.63 and 0.53 \\
\hline External Walls Materials/ thickness & $\begin{array}{c}\text { Outside, Brickwork, Cement mortar, Polyurethane foam, Brick, Gypsum } \\
\text { plastering, Inside/ } 30 \mathrm{~cm}\end{array}$ \\
\hline Heat transfer coefficient (U) - external walls & $0.43 \mathrm{Wm}^{2} \mathrm{~K}$ \\
\hline $\begin{array}{l}\text { Thermal insulation material of external walls } \\
\text { and thickness }\end{array}$ & Polyurethane foam, $5 \mathrm{~cm}$ \\
\hline Thermal insulation material of the roof & Polyurethane foam, $5 \mathrm{~cm}$ \\
\hline
\end{tabular}

Table 3 The layout of the P6 model

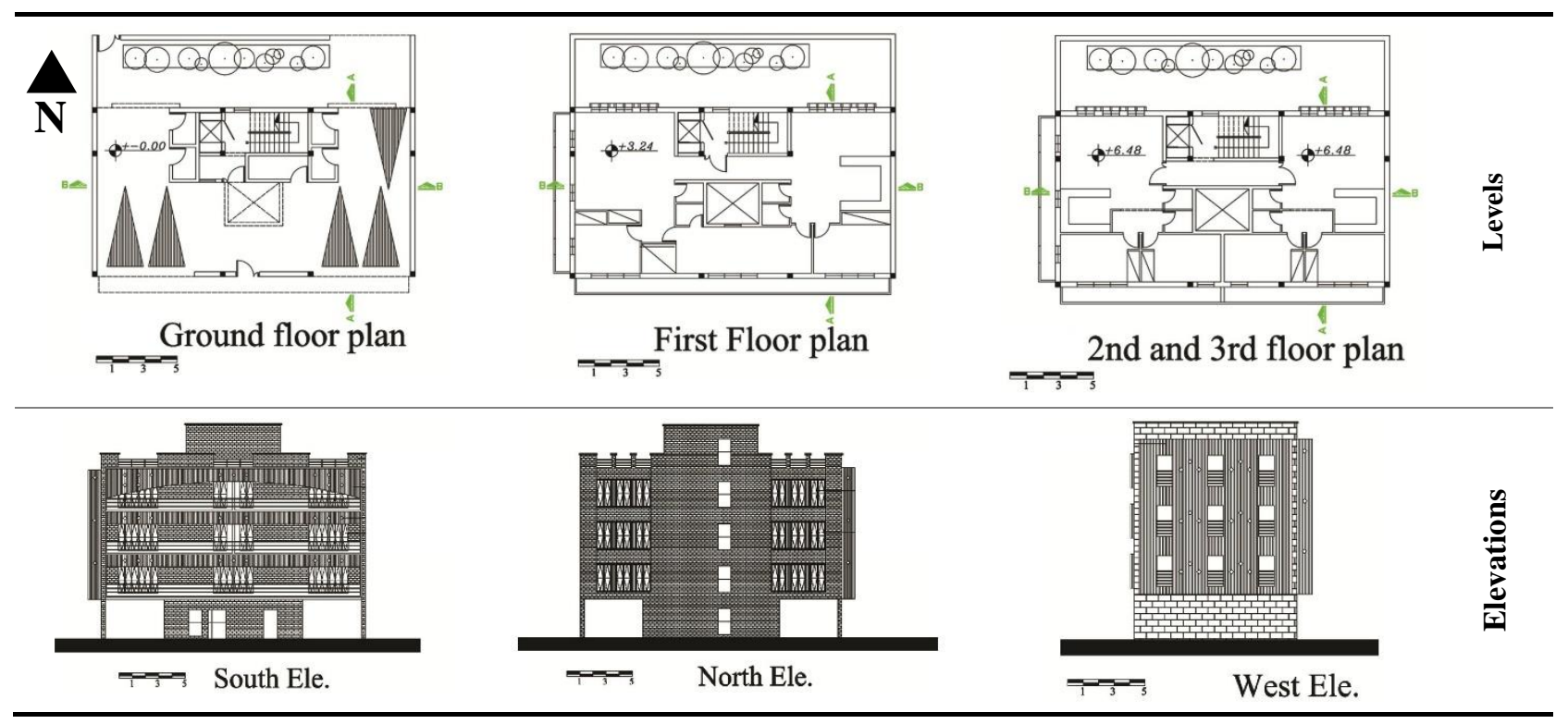

\subsection{Modeling and Simulation}

To model the 9 located buildings in different arrangements, Design Builder software was used. Simulation results of $\mathrm{Pl}-\mathrm{P} 9$ in Figure 8 show that $\mathrm{P} 6$ is the worst-case scenario for the building energy performance compared to other arrangements. Therefore, in the following, instead of designing 9 different models of a net-zero energy building for 9 different arrangements, we would concentrate on 
designing a model for $\mathrm{P} 6$ since this is the most challenging arrangement of a building in a neighborhood like RN1 in terms of annual energy consumption.

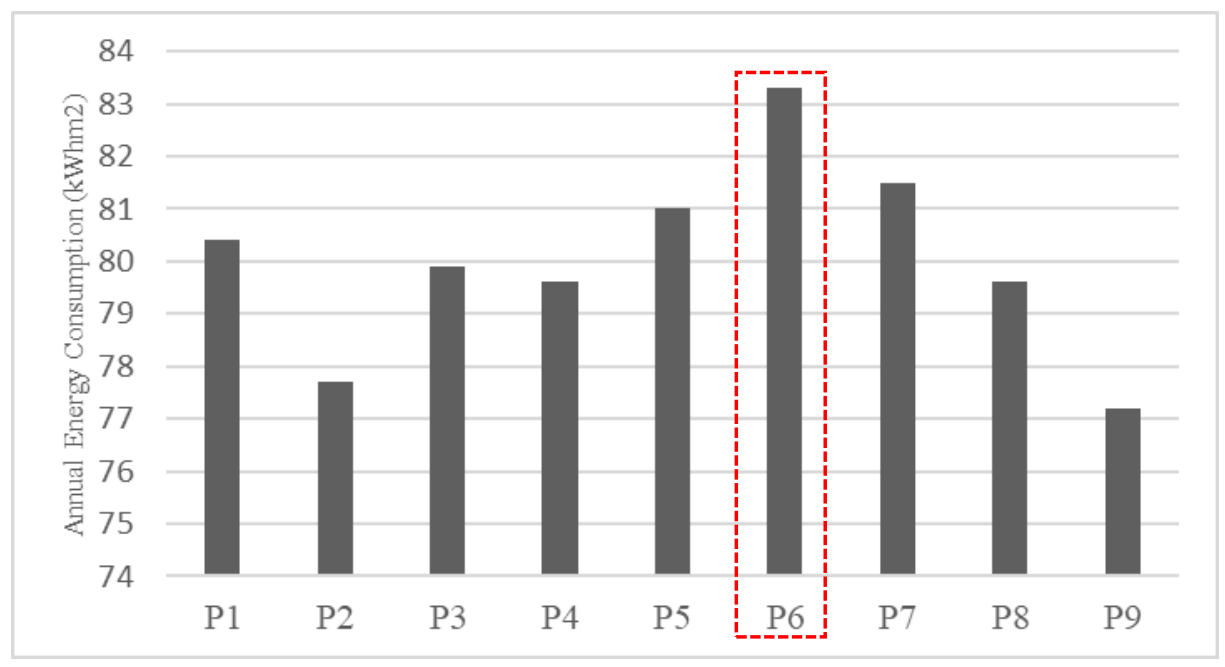

Figure 8 Annual energy consumption of P1-P9

A low-energy simulated model (LESM) of multifamily residential buildings with an area of $1187 \mathrm{~m}^{2}$ has already been developed for P6 in the literature [46]. This simulated model can be used for research on optimizing the energy demand of existing and new dwellings in the Persian Gulf region. We would use this model in designing a net-zero energy model. Figures 9 and 10 illustrate the different levels of this model and the view from different angles, respectively.

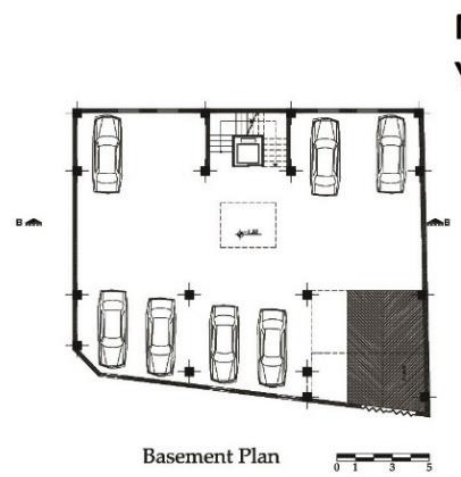

(a)

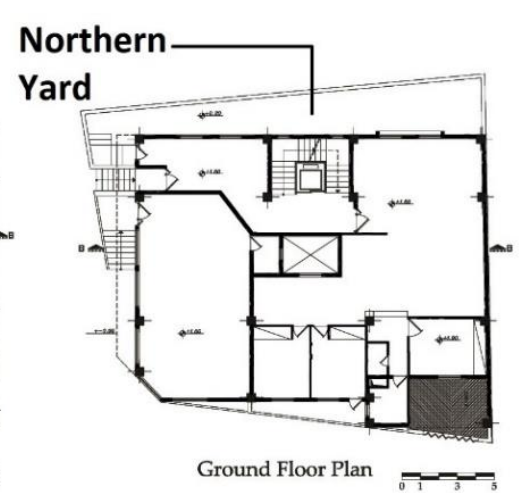

(b)

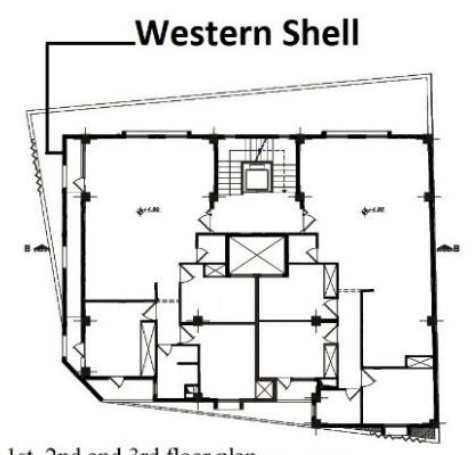

1st, 2nd and 3rd floor plan $\mathrm{P}_{1}=$

(c)

Figure 9 Different levels of LESM: a) basement, b) ground floor, and c) first to third floors (Source: Mohammadi \& Daraio [46])

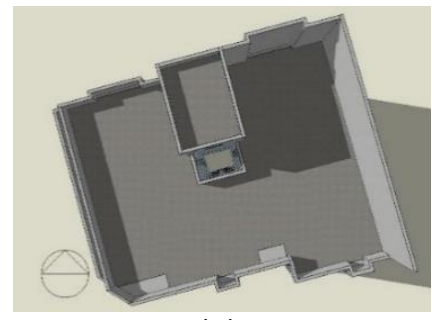

(a)

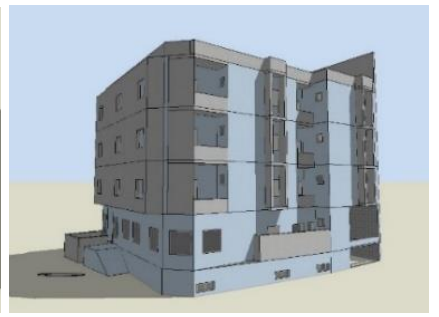

(b)

Figure 10 (a) View from the top and b) view from the southwest in Design Builder software (Source: Mohammadi \& Daraio [46])

This model uses passive measures like thermal insulation, natural ventilation, shading, Low-E glazing, and pre-heating of DHW, and benefits from a smart and energy-efficient lighting system as an active solution [46]. Table 4 shows the physical characteristics and equipment of LESM. 
Table 4 Equipment and Physical characteristics of LESM

\begin{tabular}{|c|c|}
\hline Equipment and Physical properties & Case Study Building \\
\hline Area & $1187 \mathrm{~m}^{2}$ \\
\hline Shading in the North & Overhang/Side fins with $40 \mathrm{~cm}$ depth \\
\hline Shading in the South & Overhang/Side fins with $60 \mathrm{~cm}$ depth \\
\hline Shading in the West & Vertical Shell with $80 \mathrm{~cm}$ depth \\
\hline Shading in the East & NA \\
\hline Schedule of Natural Ventilation & March and April \\
\hline Set-point for Natural Ventilation & $24^{\circ} \mathrm{C}$ \\
\hline Infiltration Rate & $1 \mathrm{~h}^{-1}$ \\
\hline Cooling, seasonal CoP, and schedule & The split unit, 1.8, May to December \\
\hline Cooling Set-point & $25^{\circ} \mathrm{C}$ \\
\hline Heating, seasonal CoP, and schedule & Radiator and gas heater, 0.85, January and February \\
\hline Heating Set-point & $18^{\circ} \mathrm{C}$ \\
\hline Lighting & Light-emitting diode with the power density of $1 \mathrm{Wm}^{2}$ \\
\hline DHW, seasonal CoP & The gas-fired hot water system with pre-heating, 0.85 \\
\hline Thickness and material of window frame & $4 \mathrm{~cm}$ UPVC \\
\hline Number of panes and glass type & Double pane with $13 \mathrm{~mm}$ of the air layer, Low-E \\
\hline Heat transfer coefficient of glass & $1.62 \mathrm{Wm}^{2} \mathrm{~K}$ \\
\hline SHGC and DST of glass & 0.29 and 0.20 \\
\hline External Walls Materials/ thickness & $\begin{array}{l}\text { Outside, Marble, Cement mortar, Clay block, Gypsum plastering, } \\
\text { Inside/ } 25 \mathrm{~cm}\end{array}$ \\
\hline $\begin{array}{l}\text { Thermal insulation material of external walls } \\
\text { and thickness }\end{array}$ & $3 \mathrm{~cm}$ of Polystyrene foam $+5 \mathrm{~cm}$ of rolled polystyrene \\
\hline Heat transfer coefficient (U) - external walls & $2.01 \mathrm{Wm}^{2} \mathrm{~K}$ \\
\hline Thermal insulation material of the roof & Rolled glass wool, $20 \mathrm{~cm}$ \\
\hline Thermal insulation material of the ceiling & Rolled glass wool, $14 \mathrm{~cm}$ \\
\hline
\end{tabular}

The energy use intensity (EUI) of this model is 75.93 $\mathrm{kWh} / \mathrm{m}^{2}$ year, which is consistent with Iranian norms for very low-energy buildings [46] and the norms of the Middle East region for low-energy houses [47]. In the initial study of this model, energy retrofitting cost was estimated at 3,328,815,000 IRRs, with a payback period of 7 years which only makes sense when the energy subsidies are eliminated. The required energy for cooking, DHW, and heating is supplied by gas consumption. But, the required energy in other sections, including cooling, lighting, and home appliances is provided by electricity consumption. The annual energy consumption in different sections of this model has shown in Figure 11. According to this figure, LESM consumes $16958.34 \mathrm{kWh}, 8975 \mathrm{kWh}$, and $406.25 \mathrm{kWh}$ of gas in the cooking, domestic hot water, and heating sections, respectively, while in the cooling, lighting, and home appliances it consumes $42257 \mathrm{kWh}, 3480 \mathrm{kWh}$, and $17476 \mathrm{kWh}$ of electricity, respectively.

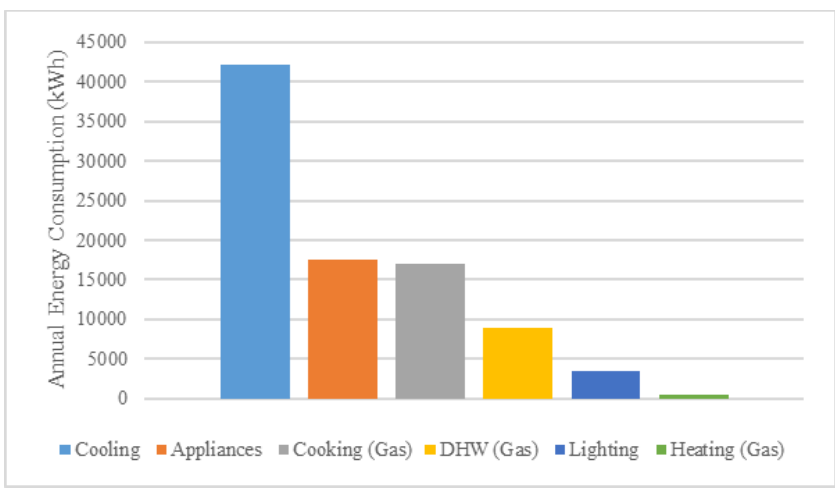

Figure 11 Annual energy consumption of LESM in different sections

The distribution of cooling loads in LESM has shown in Figure 12. According to this figure, after solar gains, electric equipment and cooking have the greatest contribution in the distribution of the cooling loads. The conventional electric appliances as well as gas stoves used in the LESM do not have an energy label 
and increase internal heat gains. To reduce the cooling loads, conventional electric appliances and gas stoves should be replaced by energy-efficient ones with low power density. Besides, instead of using conventional water heaters, Air Source Heat Pump
(ASHP) water heaters can be used to supply hot water and to capture and reduce the internal heat gains from other internal sources. The performance mechanism of an ASHP water heater has shown in Figure 13.

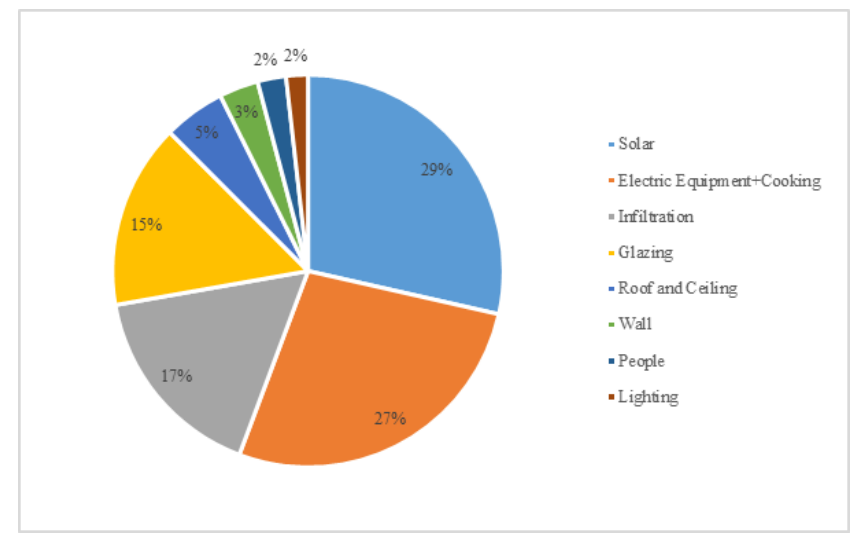

Figure 12 Distribution of cooling loads (KW) in LESM

To achieve a net-zero energy model (NZEM), the following active and renewable strategies were utilized in LESM. Therefore, NZEM benefits from a combination of passive, active, and renewable strategies. These strategies can be used for achieving NZEM for different settings of residential buildings $(9$ different arrangements in Figure 7) in Southern Iran and other similar regions. Besides, they were selected and proposed based on their compatibility with the climatic conditions of this region and their technical specifications.

\subsubsection{Energy Efficient Home Appliances}

Table 5 compares the features of home appliances in LESM and NZEM. According to this table, the devices replaced in NZEM have a significantly lower power density than LESM and have an energy label. Thus, they produce less heat indoors and reduce cooling loads and cooling energy demand.

Table 5 Comparison of home appliance features used in NZEM and LESM

\begin{tabular}{|c|c|c|c|c|c|}
\hline \multicolumn{3}{|c|}{ NZEM } & \multicolumn{3}{|c|}{ LESM } \\
\hline $\begin{array}{c}\text { Home } \\
\text { Appliances }\end{array}$ & $\begin{array}{l}\text { Power Density } \\
\quad\left(w^{2}\right)\end{array}$ & Energy Label & $\begin{array}{c}\text { Home } \\
\text { Appliances }\end{array}$ & $\begin{array}{l}\text { Power Density } \\
\left(w^{2}\right)\end{array}$ & Energy Label \\
\hline TVs & 2 & Energy Star & TVs & 3 & $\begin{array}{c}\text { Without Energy } \\
\text { Label }\end{array}$ \\
\hline $\begin{array}{l}\text { Set-top Boxes } \\
\text { (STBs) }\end{array}$ & $1.5,0.75$ & Energy Star & $\begin{array}{l}\text { Set-top Boxes } \\
\text { (STBs) }\end{array}$ & 8 & $\begin{array}{c}\text { Without Energy } \\
\text { Label }\end{array}$ \\
\hline Refrigerators & $3.75,2.5$ & Energy Star & Refrigerators & 15,10 & $\begin{array}{c}\text { Without Energy } \\
\text { Label }\end{array}$ \\
\hline Electric Stoves & 30,20 & $A+$ & Gas Stoves & 160,130 & $\begin{array}{c}\text { Without Energy } \\
\text { Label }\end{array}$ \\
\hline
\end{tabular}

\subsubsection{Air Source Heat Pump (ASHP) Water Heater}

In addition to the energy-efficient home appliances, NZEM uses an ASHP with the features listed in Table 6 instead of the conventional water heater for hot water supply. Instead of producing heat directly, ASHPs use electricity to transfer heat from one place to another. For a better understanding of ASHPS concept, one can imagine a refrigerator that works in reverse. While a refrigerator removes heat from a closed chamber and releases it into the surrounding air, an ASHP captures heat from the surrounding air and delivers it to the water in a closed tank. In case of high demand for hot water, ASHPs automatically switch to the standard state of heat generation from electrical resistance. Therefore, they can be named hybrid water heaters. Figure 13 shows the ASHP performance mechanism. 
Table 6 Comparison of hot water system characteristics in NZEM and LESM

\begin{tabular}{|c|c|c|c|c|c|c|c|c|c|}
\hline \multicolumn{5}{|c|}{ NZEM } & \multicolumn{5}{|c|}{ LESM } \\
\hline Type & CoP & Fuel & $\begin{array}{c}\text { Energy } \\
\text { Label }\end{array}$ & $\begin{array}{l}\text { Delivery and } \\
\text { Supply } \\
\text { water } \\
\text { Temperature } \\
\left({ }^{\circ} \mathrm{C}\right)\end{array}$ & Type & CoP & Fuel & $\begin{array}{c}\text { Energy } \\
\text { Label }\end{array}$ & $\begin{array}{l}\text { Delivery and } \\
\text { Supply } \\
\text { water } \\
\text { Temperature } \\
\left({ }^{\circ} \mathrm{C}\right)\end{array}$ \\
\hline $\begin{array}{l}\text { Heat } \\
\text { Pump }\end{array}$ & 3.7 & $\begin{array}{l}\text { Electricity from } \\
\text { grid }\end{array}$ & $\begin{array}{l}\text { Energy } \\
\text { star }\end{array}$ & 65,40 & $\begin{array}{l}\text { Gas-fired hot } \\
\text { water system }\end{array}$ & 0.85 & Gas & $\begin{array}{c}\text { Without } \\
\text { Energy } \\
\text { Label }\end{array}$ & 65,40 \\
\hline
\end{tabular}
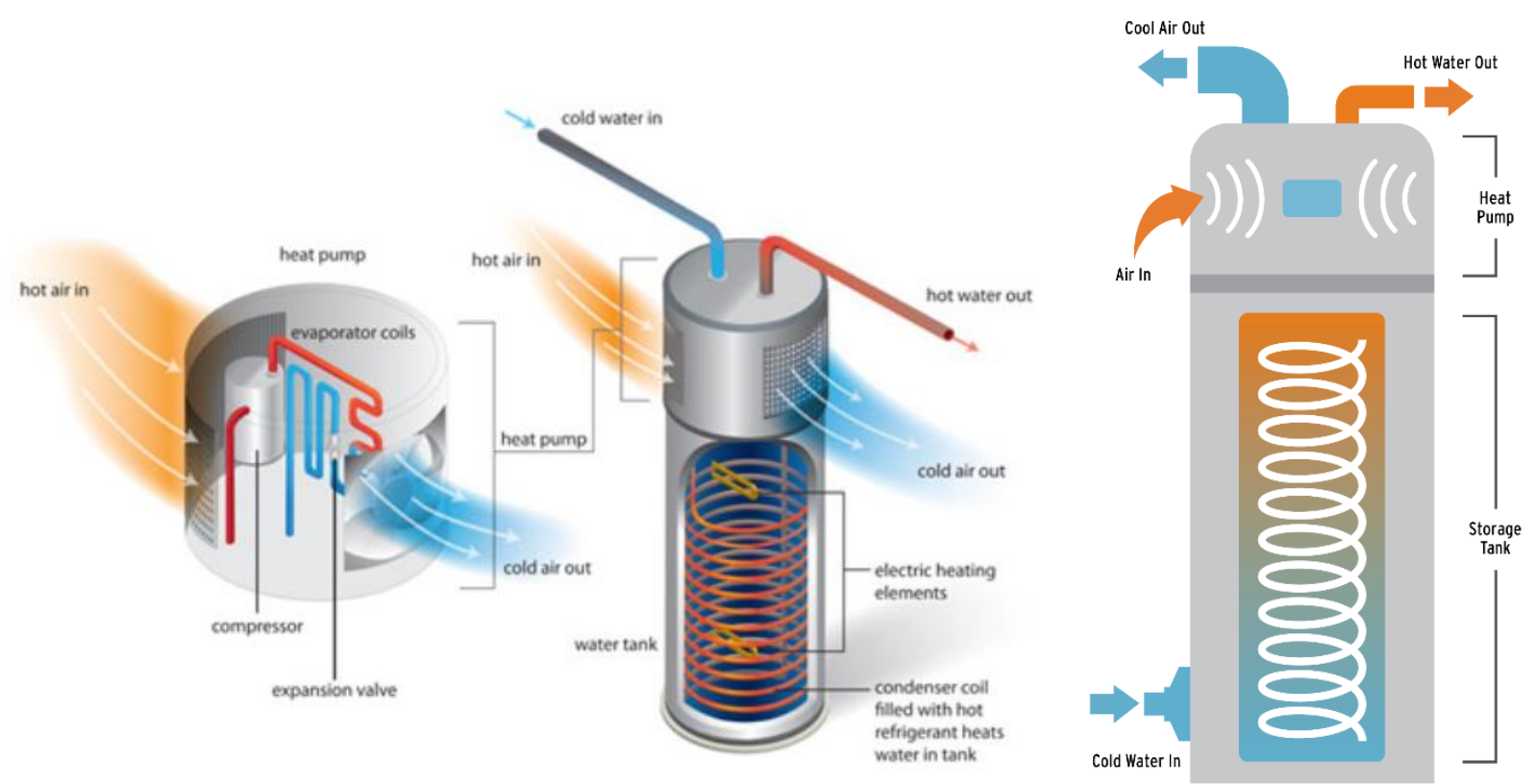

Figure 13 ASHP performance mechanism used in NZEM (Source: U.S. Department of energy)

\subsubsection{Renewable Energy}

In this study, photovoltaic panels consisting of Monocrystalline Silicon cells were used in a gridconnected system such as Figure 14 to generate electricity. In the case of generating extra energy by the PV system, additional electricity is sent to the grid.
In comparison, whenever the PV system creates less electricity than demand, the building uses the electricity from the grid. Thus, there is no demand for battery storage, and the costs, the maintenance of the solar power system, and the amount of energy loss could be reduced [48]. Schematics of this process have shown in Figure 15. 


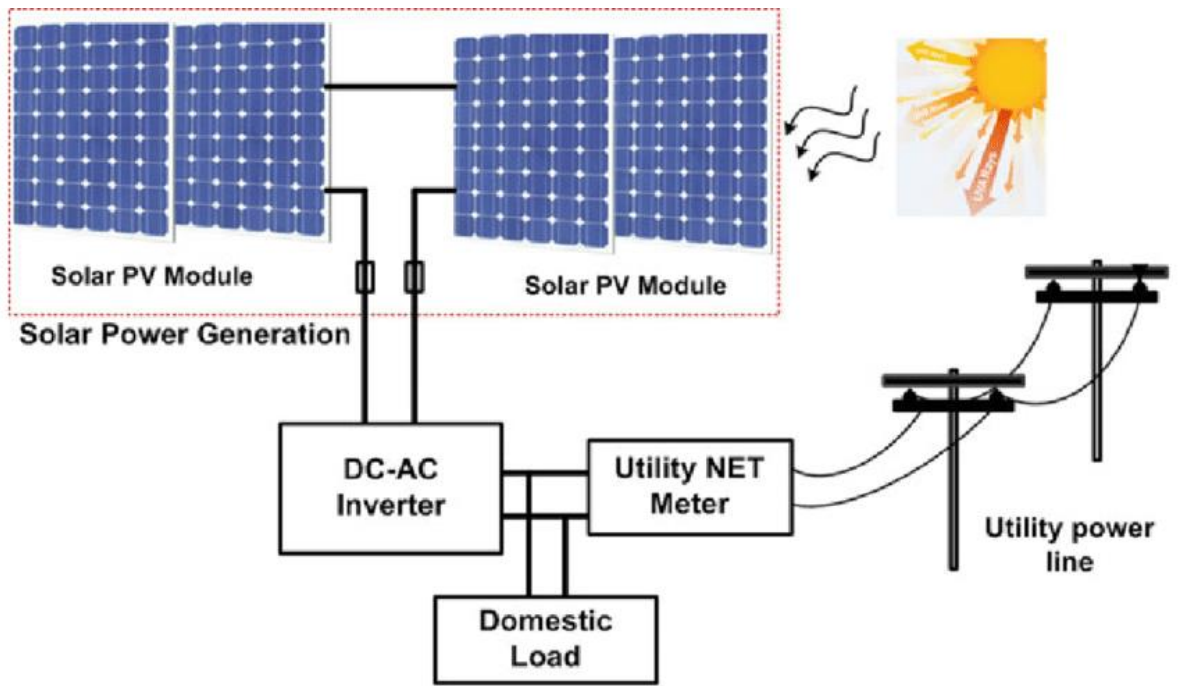

Figure 14 Grid-connected photovoltaic system (Source: Karthikeyan, V., et al. [49])

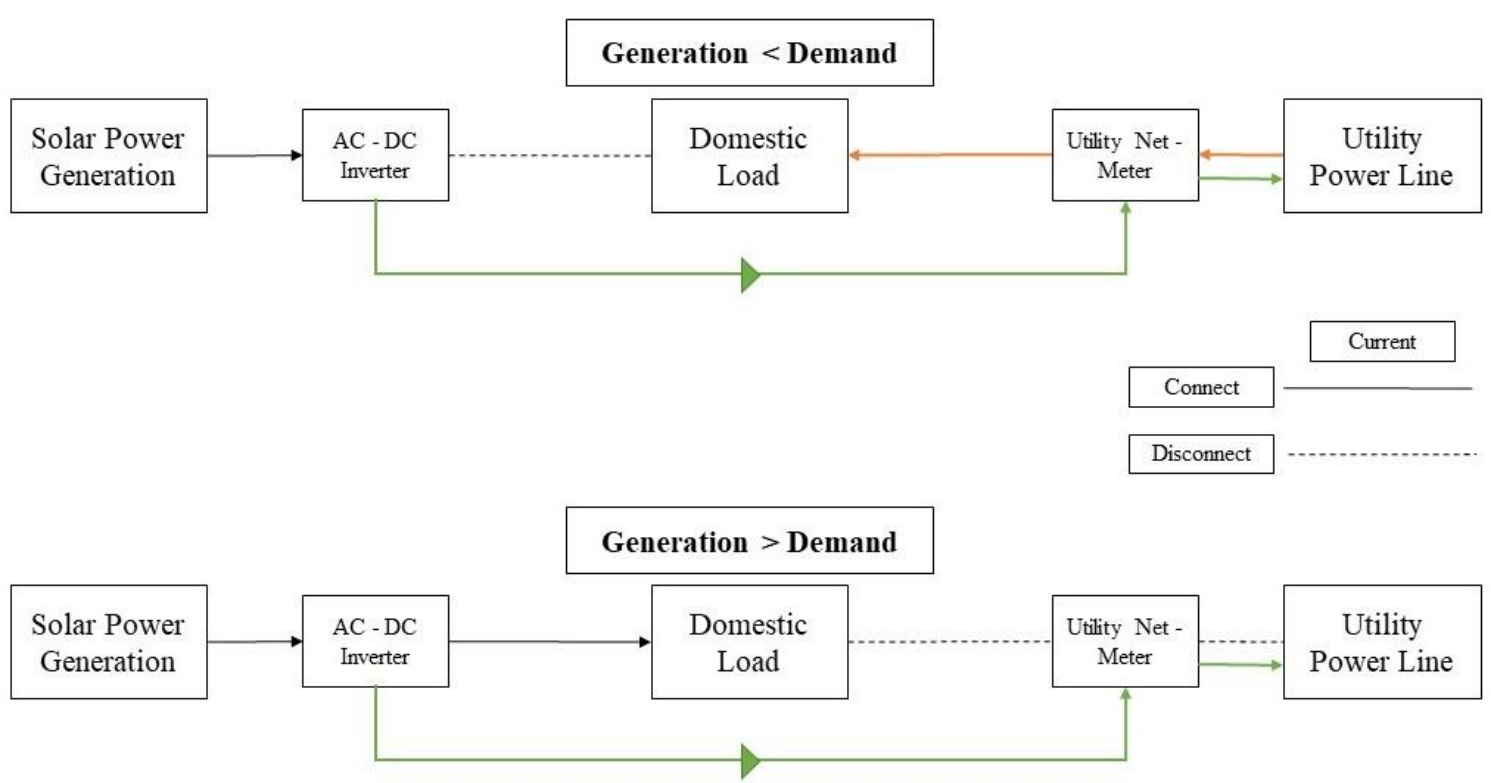

Figure 15 Schematics of electricity exchange when generation and demand are not equal

It is important to provide the space needed to install PV panels to design photovoltaic systems. As the LESM roof surface area is not sufficient due to the existing barriers (movement routes and ventilation ducts), an additional prefabricated concrete roof with a thickness of $20 \mathrm{~cm}$ was designed to install the panels on it. For service and maintenance purposes, there are walking spaces between the PV panels. Figure 16 and Table 7 show the location and area for the installation of photovoltaic panels in NZEM, respectively. 


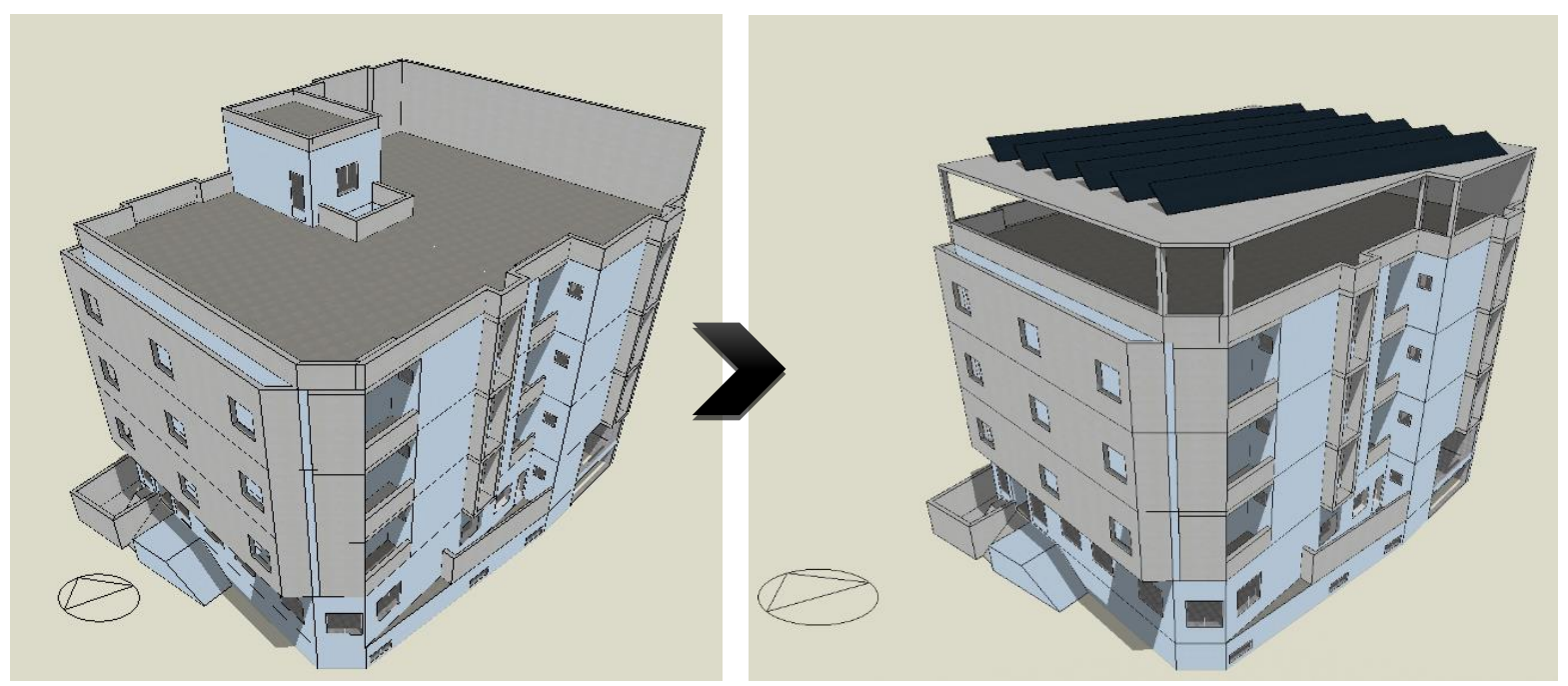

Figure 16 Location for installation of photovoltaic arrays in NZEM

Table 7 Areas of arrays used in NZEM

\begin{tabular}{ccc}
\hline Available area $\left(\mathbf{m}^{2}\right)$ & The total area of PV panels $\left(\mathbf{m}^{2}\right)$ & Number of PV panels \\
\hline Roof & Fixed tilt angle $\left(29^{\circ}\right)$ & Fixed tilt angle $\left(29^{\circ}\right)$ \\
\hline 270 & 160.32 & 96 \\
\hline
\end{tabular}

The tilt angle of the panels is equivalent to the location's latitude $\left(29^{\circ}\right)$ considered towards the south. The characteristics of the panels used in this study are presented in Table 8. These features were used in the modeling and simulation of the panels.

Table 8 The characteristics of photovoltaic panels used in NZEM (Source: SolarWorld [50])

\begin{tabular}{|c|c|c|c|}
\hline Panel characteristics & Value & Panel characteristics & Value \\
\hline Gross area of the panel with frame $\left(\mathrm{m}^{2}\right)$ & 1.676675 & $\begin{array}{l}\text { Rated electric power output per module } \\
\text { (W) }\end{array}$ & 300 \\
\hline The active area of the panel $\left(\mathrm{m}^{2}\right)$ & 1.46016 & Short circuit current (A) & 9.83 \\
\hline Panel dimensions (mm) & $1001 \times 1675$ & Module current at maximum power (A) & 9.31 \\
\hline Operating range & $-40^{\circ} \mathrm{C}-+85^{\circ} \mathrm{C}$ & $\begin{array}{c}\text { Temperature coefficient of short circuit } \\
\text { current (AK) }\end{array}$ & +0.006881 \\
\hline Weight & $18 \mathrm{Kg}$ & Open circuit voltage (V) & 40 \\
\hline Cells per module & 60 & $\begin{array}{c}\text { Rated voltage (Module voltage at } \\
\text { maximum power) (V) }\end{array}$ & 32.6 \\
\hline Cell dimensions (mm) & $156 \times 156$ & $\begin{array}{c}\text { Temperature coefficient of open-circuit } \\
\text { voltage (VK) }\end{array}$ & -0.116 \\
\hline Maximum system voltage IEC (V) & 1000 & Module efficiency (\%) & 17.89 \\
\hline
\end{tabular}

The required numbers of the photovoltaic panel were determined according to the available space area and NZEM annual electricity demand. The number of panels required to supply electricity to a building can be calculated using Eq. (1) to Eq. (3) [51]:

$$
\begin{gathered}
\text { Number of } P V \text { panels }=P \text { inv }(P \text { max. actual }) ;(1) \\
P \text { inv }=P_{\text {Demand }} \eta_{\text {inv. }}(2) \\
P \text { max. actual }=P \text { max } \times P S H\left[(1-I t) \times\left(1-I_{c}\right) \times(1-I \text { m })\right] \times \\
365(3)
\end{gathered}
$$

Where $P_{\text {inv }}$ is the invertor electricity output (kWh), $P$ max. actual is electricity generated by each panel per year $\left(\mathrm{kW}_{\mathrm{p}} \mathrm{h}\right)$, PDemand is the annual electricity demand $(\mathrm{kWh})$, and $\eta_{\text {inv }}$ is the inverter efficiency (equal to 98\%). Also, $P_{\max }$ is the peak power of a panel at maximum irradiance $(\mathrm{KW}), \mathrm{PSH}$ is the average of peak sun-hours (h), and I t, I c, and I m are the temperature losses coefficient, the cable losses coefficient, and the modules losses coefficient, respectively. The findings of the simulation experiment reveal that the annual electricity demand of NZEM is $46.28 \mathrm{MWh}$. By dividing this value by the inverter efficiency, $\mathrm{P}_{\text {inv }}$ will be $47.22 \mathrm{MWh}$. If the temperature losses coefficient, the cable losses coefficient, and the modules losses coefficient are assumed $12.5 \%, 5 \%$, and $5 \%$, respectively, and $\mathrm{PSH}$ 
value for Bushehr according to Figure 2 is considered 5.7, Pmax.actual will be $492.88\left(\mathrm{~kW}_{\mathrm{p}} \mathrm{h}\right)$. Therefore, 96 panels will be required to supply power. Arrangement and the number of these panels in series lines ( $N_{\text {in series) }}$ can be calculated using Eq. (4) [51]:

$\mathrm{N}$ in series $=$ Maximum system voltage Rated voltage

According to Eq. 4 and the values of Table 8, about 31 photovoltaic panels must be installed in series lines. As 96 panels are needed for installation on the new roof, the number of parallel lines will be 3 . However, as the new roof space is not large enough to put 31 panels in one row, 6 parallel lines, each consisting of 16 series panels, are used instead (Figure 17). Therefore, 32 panels in two connected 16 lines will be connected in series and there will be three parallel lines. This 29-kilowatt grid-connected system is expected to cover the annual electricity demand of NZEM.

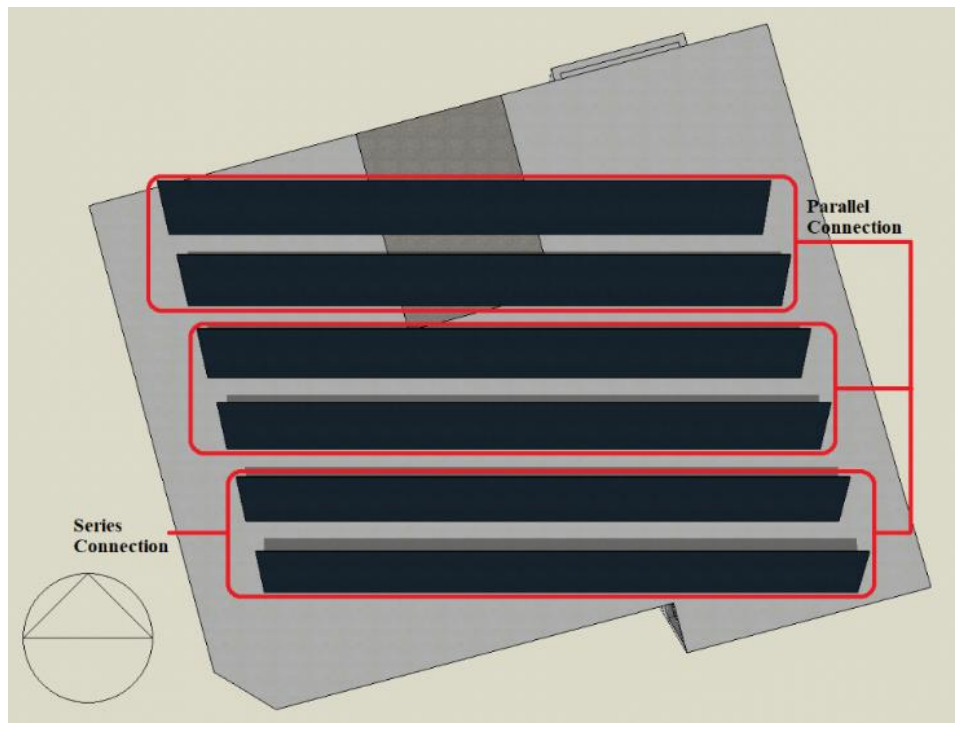

Figure 17 Photovoltaic panel arrangement

Moreover, the power supplied by the system to the grid is determined using Eq. (5) [52]:

$$
E_{\text {delivered }}=P_{\text {inv. }} \times \eta_{\text {abs. }}
$$

Where $E_{\text {delivered }}$ is the electricity sent to the grid in $\mathrm{kWh}, \mathrm{P}_{\text {inv }}$ is invertor output electricity rate in $\mathrm{kWh}$, and $\eta_{\text {abs }}$ is grid absorption rate equal to $99 \%$.

\subsection{RESULTS AND DISCUSSION}

To compare the simulation results with the main objectives of this study according to the research framework in Figure 1, the findings were categorized in three sections including thermal comfort improvement, energy-saving/production, and Cost/Carbon reduction, and discussed as follow:

\subsection{Thermal Comfort Improvement}

Since thermal comfort improvement is one of the main objectives in NZEB design in this study, it should be analyzed and discussed. To analyze and compare the internal thermal comfort conditions in LESM and NZEM, important factors including space heat gains and sensible cooling, predicted mean vote (PMV) and predicted percentage of dissatisfaction (PPD) in ASHRAE standard 55, and discomfort hours were discussed, respectively. There are two different models for evaluating thermal comfort conditions inside buildings in ASHRAE standard 55-2010 [53]. The Adaptive models for freerunning buildings and the Predicted Mean Vote (PMV) and the predicted percentage of dissatisfied (PPV) models for air-conditioned buildings. Since our building models use the split air conditioner for cooling in a hot and humid climate, the PMV/PPV model in the ASHRAE standard 55 was used for evaluating internal thermal comfort conditions in this study.

The results obtained from the simulation in Design Builder software in Figure 18 show that because of using energy-efficient and very low power density home appliances and ASHP water heater in NZEM (according to Tables 5 and 6), the total space heat gains, and zone sensible cooling decreased from 67476.71 kWh and 55893.57 kWh in LESM to 40655.76 $\mathrm{kWh}$ and $40611.29 \mathrm{kWh}$ in NZEM, respectively. This means reductions of $40 \%$ and $27 \%$ in total space heat gains and zone sensible cooling, respectively. 


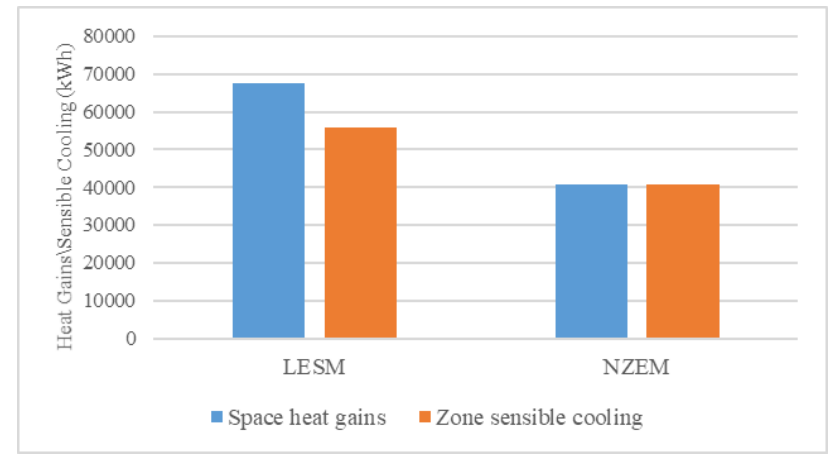

Figure 18 Total space heat gains and zone sensible cooling

To make sure that internal thermal comfort conditions in NZEM were optimized compared to LESM, this study used the predicted mean vote (PMV) index of ASHRAE standard 55. This index uses seven factors including activity levels, clothing, airspeed, relative humidity, air temperature, mean radiant temperature, and operative temperature for evaluating the internal thermal comfort conditions. While the factors like activity levels, clothing, and airspeed remained unchanged in LESM and NZEM according to table 9, the average values of air temperature, radiant temperature, and operating temperature decrease from $25.42^{\circ} \mathrm{C}, 25.66^{\circ} \mathrm{C}$, and $25.54^{\circ} \mathrm{C}$ in LESM to $24.80^{\circ} \mathrm{C}, 25^{\circ} \mathrm{C}$, and $24.90^{\circ} \mathrm{C}$ in NZEM, respectively due to the significant reduction in power density of home appliances and space heat gains in NZEM. Besides, according to Table 9 and Figure 19, the mean indoor thermal comfort indices (i.e. PMV and PPD in ASHRAE standard 55) decreased from 0.40 and 8.29 in LESM to 0.21 and 5.90 in NZEM, respectively, suggesting the significant improvement of indoor thermal comfort conditions in NZEM.

Table 9 Comparison of temperatures and thermal comfort indices in LESM and NZEM (Source: Design Builder software)

\begin{tabular}{ccc}
\hline $\begin{array}{c}\text { Average of temperatures (all } \\
\text { thermal zones) }\left({ }^{\circ} \mathrm{C}\right)\end{array}$ & LESM & NZEM \\
\hline Activity $(\mathrm{MET})$ & 1 & $\mathbf{1}$ \\
\hline Clothing $(\mathrm{Clo})$ & 0.77 & $\mathbf{0 . 7 7}$ \\
\hline AirSpeed $(\mathrm{ms})$ & 0.1 & $\mathbf{0 . 1}$ \\
\hline Relative Humidity $(\%)$ & 58.75 & $\mathbf{6 1 . 1 8}$ \\
\hline Air temperature $\left({ }^{\circ} \mathrm{C}\right)$ & 25.42 & $\mathbf{2 4 . 8 0}$ \\
\hline Mean Radiant temperature $\left({ }^{\circ} \mathrm{C}\right)$ & 25.66 & $\mathbf{2 5}$ \\
\hline $\begin{array}{c}\text { Operative temperature }\left({ }^{\circ} \mathrm{C}\right) \\
\text { Average of indoor thermal comfort } \\
\text { indices (all thermal zones) }\end{array}$ & 25.54 & $\mathbf{2 4 . 9 0}$ \\
\hline LESM & $\mathbf{N Z E M}$ \\
\hline $\begin{array}{c}\text { Predicted Mean Vote }(\mathrm{PMV}) \\
\text { Predicted Percentage of } \\
\text { Dissatisfied (PPD) }\end{array}$ & 0.40 & $\mathbf{0 . 2 1}$ \\
\hline
\end{tabular}

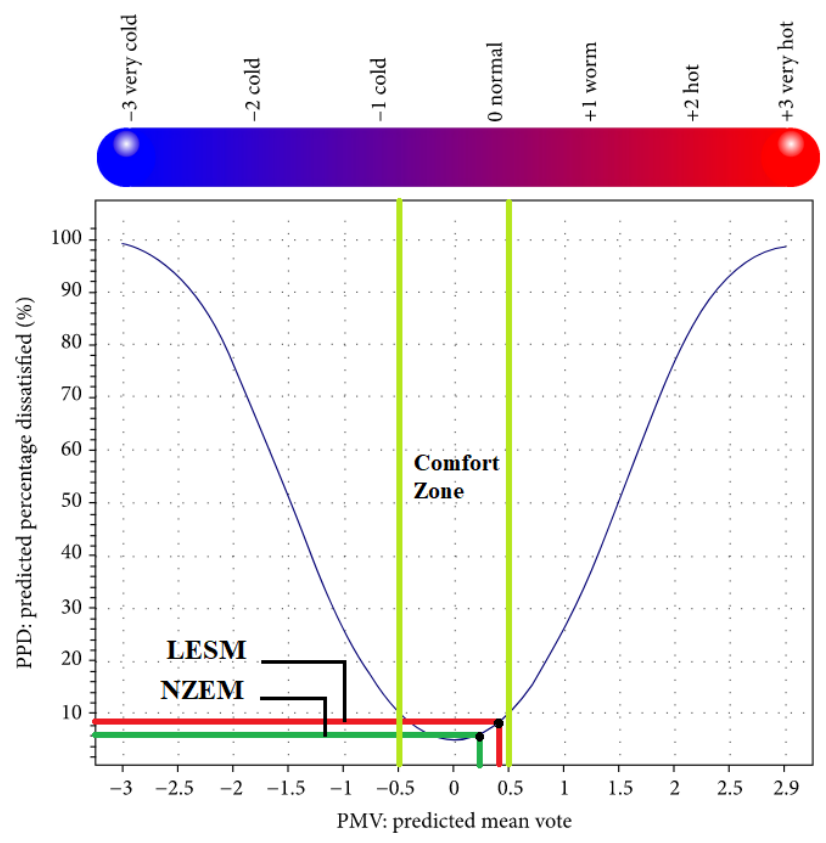

Figure 19 PMV and PPD for LESM and NZEM in thermal comfort graph (Source: Mahdavi Adeli et al. [40])

To achieve a comprehensive assessment of indoor thermal comfort, discomfort hours (DH) should be analyzed as well. To this end, a sensitivity analysis (SA) using Latin hypercube sampling (LHS) and regression method with 120 simulation runs was performed in LESM and NZEM. 


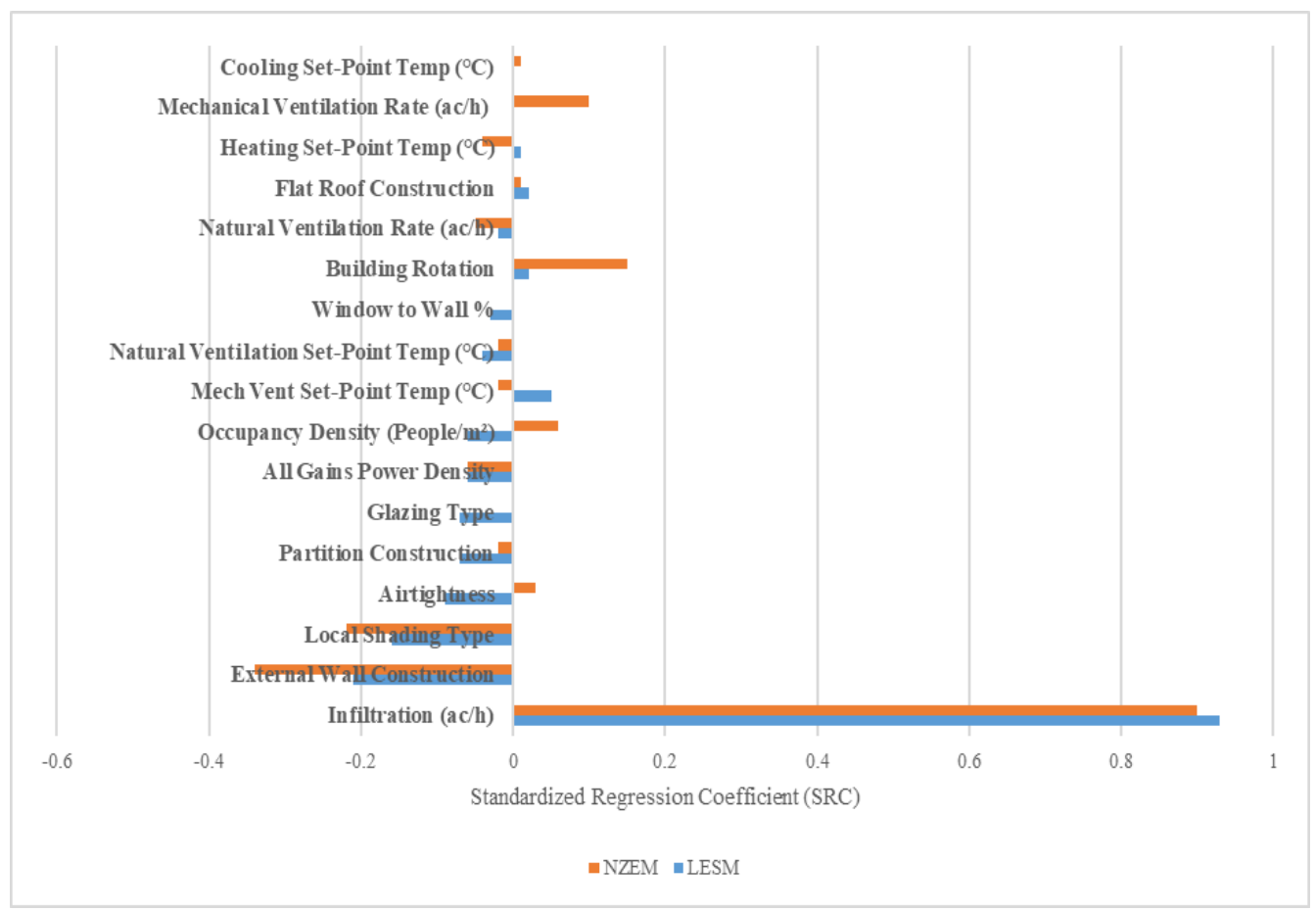

Figure 20 Sensitivity Analysis Results for Discomfort Hours (All Clothing)

Figure 20 depicts the standardized regression coefficient (SRC) of 17 different variables with $\mathrm{DH}$ in LESM and NZEM. According to this figure, among these variables, the infiltration rate with SRC of 0.93 and 0.90 in LESM and NZEM has a remarkable influence on $\mathrm{DH}$ compared with the other 16 variables in both models. Since the average infiltration rate was $1\left(\mathrm{~h}^{-1}\right)$ for both models, which match the passive house institute (PHI) low energy buildings standard [53], the average of $\mathrm{DH}$ for all thermal zones stood at 3550 hours and 3800 hours or $40 \%$ and $43 \%$ within a year for LESM and NZEM, respectively, that is an acceptable range (Table 10).

Table 10 Average of Discomfort hours (out of comfort zone) for all thermal zones in LESM and NZEM within a year

\begin{tabular}{ccc}
\hline $\begin{array}{c}\text { Average of Discomfort hours } \\
\left(25^{\circ} \mathrm{C} \leq \mathrm{T}_{\text {in }} \leq 18^{\circ} \mathrm{C}\right)\end{array}$ & LESM & NZEM \\
\hline Number (hours) & 3550 & 3800 \\
\hline Percentage (\%) & 40 & 43 \\
\hline
\end{tabular}

The results of this section clearly showed that thermal comfort improvement as one of the main objectives in NZEBs design in this study is quite feasible in a hot and humid climate like Southern Iran.

\subsection{Energy Saving/Production}

In this section, energy-saving/production in LESM and NZEM is discussed as one of the most important objectives in NZEBs design in this study.

Figure 21 depicts the annual energy consumption in various parts of LESM and NZEM. As it can be seen, the annual energy use in cooling, home appliances + cooking, and domestic hot water (DHW) has decreased from $42257 \mathrm{kWh}, 34434.26 \mathrm{kWh}$, and 8975 $\mathrm{kWh}$ in LESM to $33199.22 \mathrm{kWh}, 7702 \mathrm{kWh}$, and 1098.52 $\mathrm{kWh}$ in NZEM, respectively. This means reductions of $21.4 \%, 77.6 \%$, and $87.7 \%$ in energy consumption in these sectors. Energy consumption has not changed in the lighting sector. However, in the heating sector, energy consumption has risen from $406 \mathrm{kWh}$ in LESM to $806 \mathrm{kWh}$ in NZEM, which is negligible due to its small amount. Overall, annual energy consumption has decreased from $89553 \mathrm{kWh}$ in LESM to $46285 \mathrm{kWh}$ in NZEM, suggesting a $48 \%$ reduction in annual energy consumption.

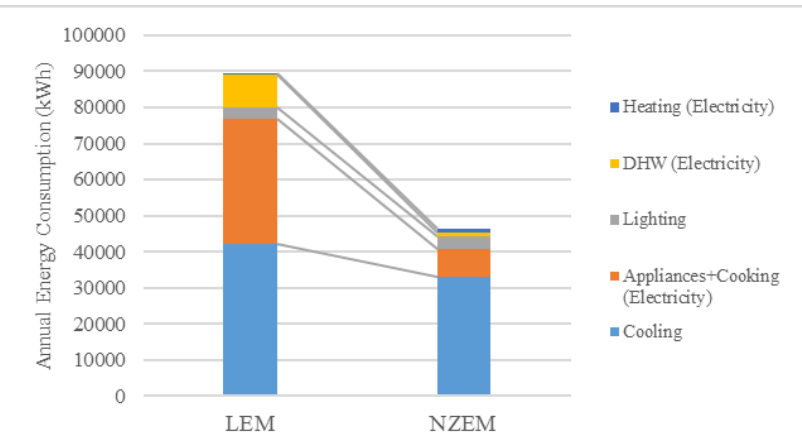

Figure 21 Annual energy consumption in different sections

The EUI of LESM and NZEM should be discussed and compared in this section. While the EUI of LESM was about $76 \mathrm{kWh} / \mathrm{m}^{2}$ year, this index was 39 $\mathrm{kWh} / \mathrm{m}^{2}$ year for NZEM which shows a reduction of 48 $\%$ for energy use intensity. In Figure 22, the EUI of 
NZEM was compared with NZEB standards for the Middle East and North Africa nations (MENA), which were made through improving the building fabric. According to NZEB standards for the MENA region in Figure 22, the EUI should range between 52-98 $\mathrm{kWh} / \mathrm{m}^{2}$ year [54]. While the EUI of NZEM was 39 $\mathrm{kWh} / \mathrm{m}^{2}$ year, suggesting better results than NZEB standards for the MENA region. This EUI can be used as a new reference in designing NZEBs in the wide area of the Persian Gulf zone.

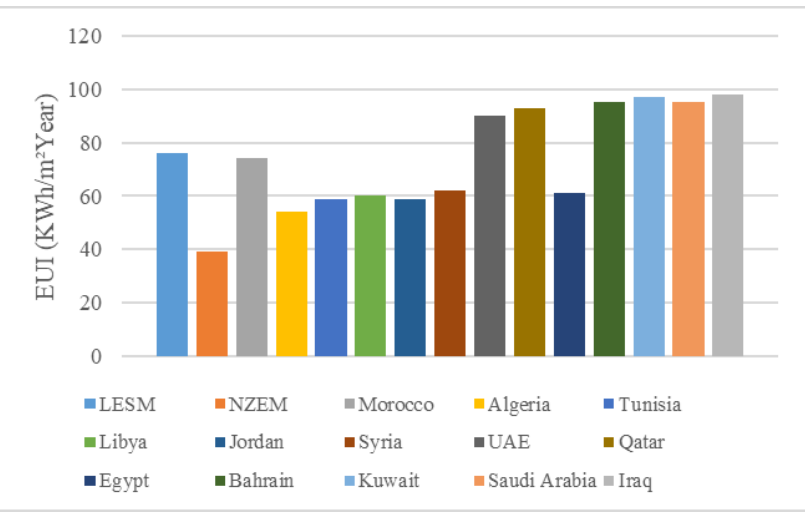

Figure 22 Benchmarking energy use intensity (EUI) with the MENA region standards

Besides, some results of this study were compared with relevant studies about Net-Zero energy residential buildings from Table 1 . As it was shown in this Table, some parameters like thermal comfort improvement, energy-saving/production, and cost/Carbon reduction have not been addressed in some studies and were shown by NA. Thus, it was not possible to compare them with the results of this study. But it can be seen from Table 1 that the results of this paper for energy-saving were better than the results of To, C., J. Li, and M. Kam [39] for Hong Kong. This Table also shows that our results for energy production were better than results of Kwan, Y. and L. Guan [32] for Australia.

In this study, a grid-connected PV system (capacity $=29 \mathrm{~kW}$ ) was used to supply the annual electricity demand of NZEM, according to Section 2.2.3. The results obtained from the simulation of this system in Figure 23 show that the annual electricity generation of this system is $52140 \mathrm{kWh}$. To balance the annual electricity demand of NZEM (46285 KWh), $27745 \mathrm{KWh}$ electricity was delivered from the utility power line, and $18540 \mathrm{KWh}$ was delivered from the $\mathrm{PV}$ system. Since the annual generation of electricity by the PV system is $52140 \mathrm{kWh}$, the surplus electricity of the PV system will be 33600 KWh, which can compensate for the annual delivered electricity from the utility power line, and $5855 \mathrm{KWh}$ extra electricity will be exported to the grid. Thus, NZEM can be considered as a plus energy model (PEM).

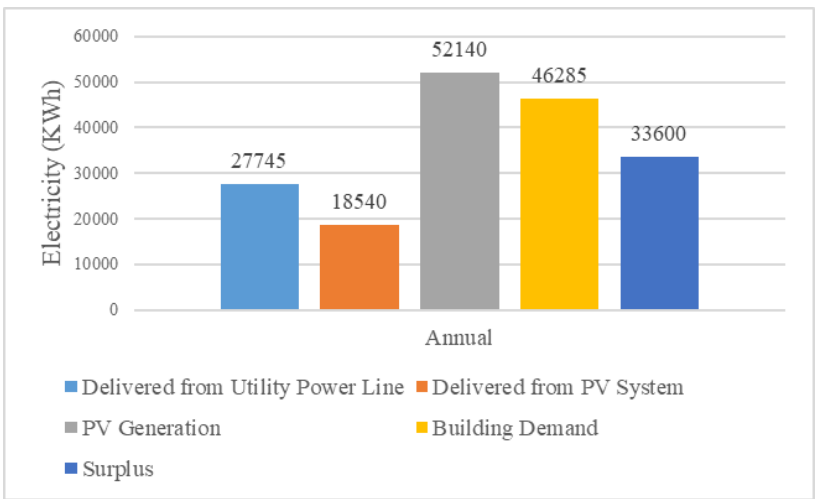

Figure 23 Simulation results for balancing the electricity demand in NZEM

It should be noted that the monthly and daily performances of the PV system must be evaluated as well. Figure 24 shows that from January to April and from October to December, the generated electricity is more than the NZEM demand, but from May to September, the generation is less than the demand. This power shortage during a year can be compensated with extra generation in the other 7 months. Besides, Figures 25 and 26 show the processes of load shifting between the PV system and the utility power line on a typical day of winter (Jan 15) and summer (July 15) in NZEM. According to these figures, the PV system cannot generate electricity at night and early morning (from 1 a.m to 8 a.m and from 6 p.m to 12 p.m in Winter, and from 1 a.m to 6 a.m and from 7 p.m to 12 p.m in Summer) and building electricity demand is supplied through the utility power line. Besides, this PV system cannot balance the building electricity demand on the hot days, from May to September, and the utility power line is used to supply the building demand. But during a day, from January to April and from October to December, the system generates more electricity than the building demand, and the surplus electricity can be sent to the grid. This surplus electricity in these periods can compensate for the power shortage at night throughout the year and during the hot days of May to September.

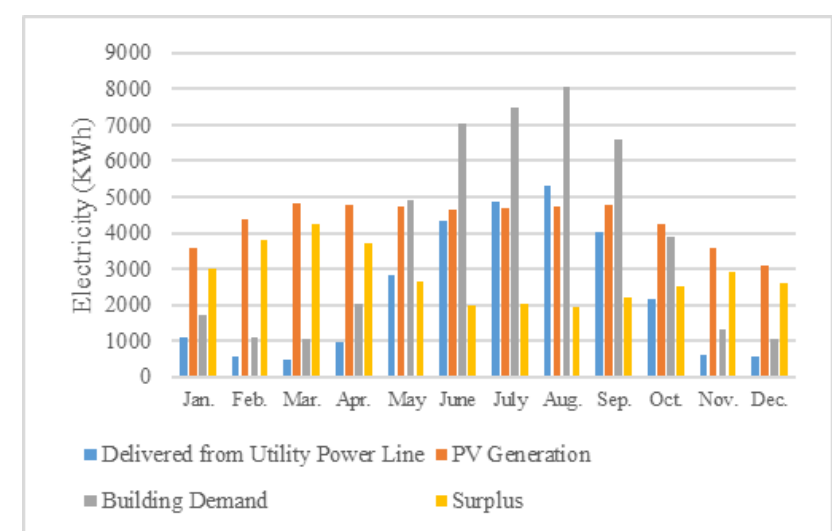

Figure 24 Monthly electricity consumption and generation in NZEM 


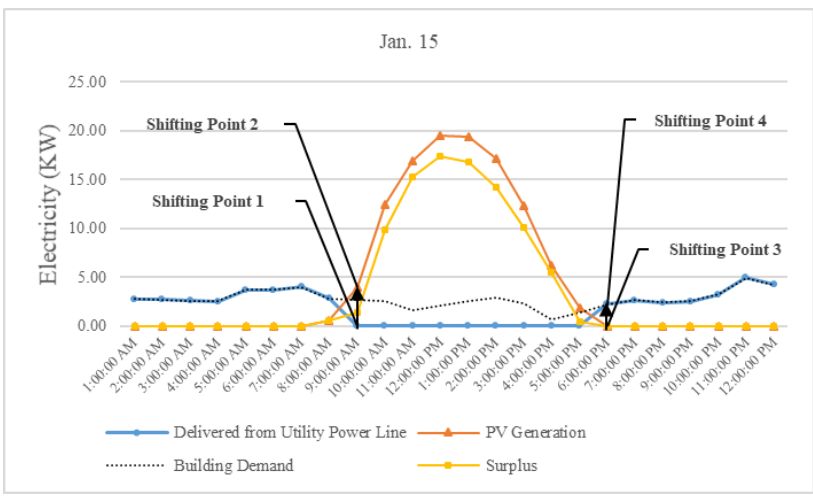

Figure 25 Load Shifting on a typical day of winter in NZEM

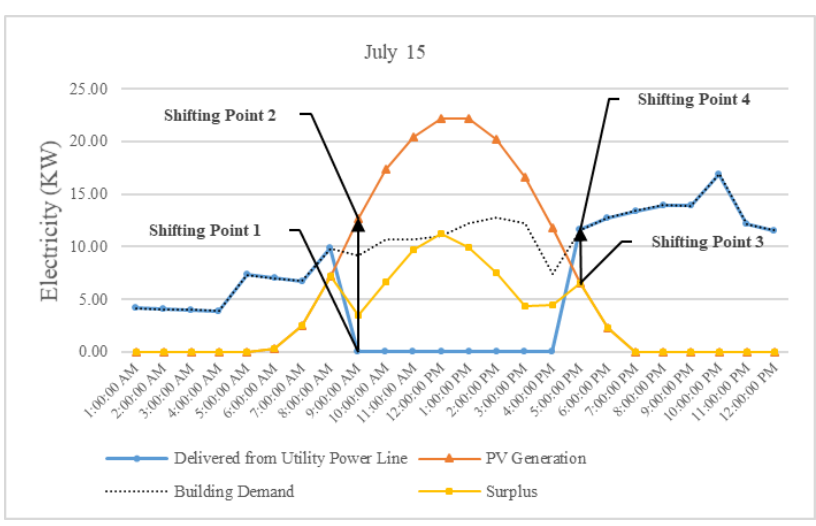

Figure 26 Load Shifting on a typical day of summer in NZEM

The findings of this section are a piece of evidence that shows a significant percentage of energy-saving/production as the main objective in NZEBs design in Southern Iran is achievable.

\subsection{Cost/Carbon Reduction}

To analyze the cost-effectiveness of the project, this research used the simple payback period method and the life cycle cost (LCC) analysis. Table 11 shows the initial costs and energy/cost saving in NZEM. According to this table, the annual energy savings of NZEM will be $43268 \mathrm{kWh}$, while $5855 \mathrm{kWh}$ extra electricity will be exported to the grid. In this study, the annual electricity cost-saving, considering subsidy, is $98,261,628$ IRRs, while without subsidy, this amount is 7 fold and reaches 713,922,000 IRRs. Considering the current electricity export rate to the grid in Iran (9100 IRR kWh) and the annual revenue of delivered electricity to the grid in this study $(53,280,500$ IRR $)$, the payback period considering the subsidies and without it will be 100 years and 20 years, respectively according to Figure 27. Nonetheless, considering the proposed electricity export rate to the grid in this study $(500,500 \mathrm{IRR} / \mathrm{KWh}$ or 2 USD/kWh), the payback period will be less than 6 years, and investment will be justified. This result for the payback period is better than the results of relevant studies in Table 1 such as Abd-Ur-Rehman, H.M., et al. [25] and Kwan, Y. and L. Guan [32] for Saudi Arabia and Australia, respectively. Such a proposed rate can be considered as a part of incentive programs that government should initiate to encourage the installation of PV systems in residential buildings. However, the findings of the economic evaluation also showed that the elimination of energy subsidies is very important to make such projects cost-effective. This result is consistent with the results of Krarti and Ihm [55] in the study of NZEBs in the MENA region.

Table 11 The initial costs and Energy/Cost saving in NZEM

\begin{tabular}{|c|c|c|}
\hline Item & \multicolumn{2}{|c|}{ Cost (IRR) } \\
\hline PV system* & \multicolumn{2}{|c|}{$4,350,000,000$} \\
\hline Home appliance & \multicolumn{2}{|c|}{$7,210,000,000$} \\
\hline Heat pump water heaters & \multicolumn{2}{|c|}{$3,500,000,000$} \\
\hline Concrete slab & \multicolumn{2}{|c|}{$169,020,000$} \\
\hline Total & \multicolumn{2}{|c|}{$15,229,020,000$} \\
\hline Energy/cost saving & $\begin{array}{l}\mathrm{KWh} / \mathrm{Ye} \\
\text { ar }\end{array}$ & IRR/Year \\
\hline Annual energy saving & 43,268 & $\cdots$ \\
\hline Annual exported electricity to the grid & 5,855 & $-\cdots$ \\
\hline Annual electricity cost saving with subsidy ( $1 \mathrm{kWh}=2,271$ IRR) & --- & $98,261,628$ \\
\hline Annual electricity cost saving without subsidy ( $1 \mathrm{kWh}=16,500$ IRR) & --- & $713,922,000$ \\
\hline Annual revenue of exported electricity to the grid ( $1 \mathrm{kWh}=9,100 \mathrm{IRR})$ & --- & $53,280,500$ \\
\hline $\begin{array}{l}\text { Annual revenue of exported electricity to the grid considering the proposed rate (1 kWh = } \\
\qquad 500,500 \text { IRR) }\end{array}$ & --- & $2,930,427,500$ \\
\hline
\end{tabular}




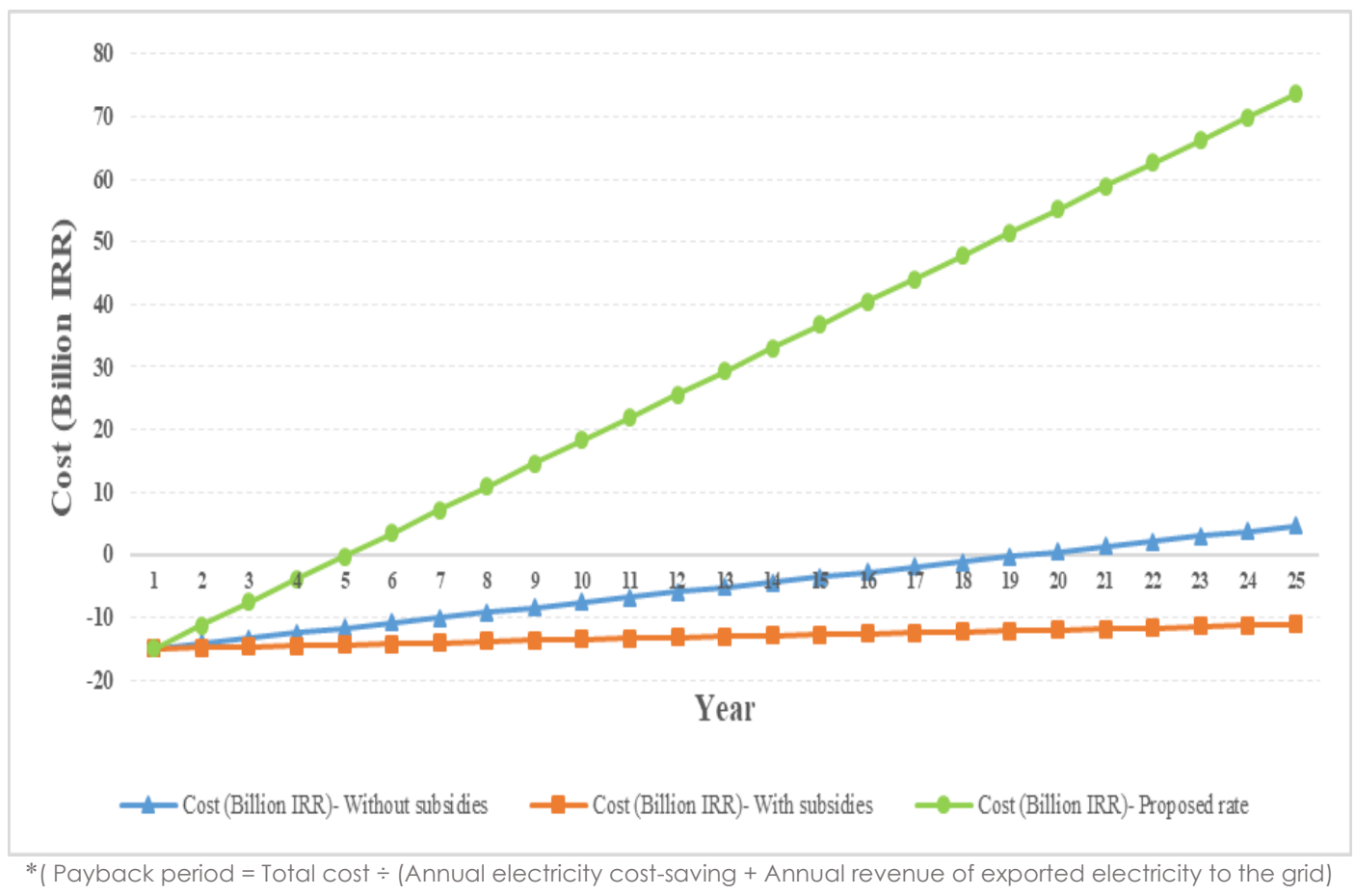

Figure 27 Payback period* diagram

For a better understanding of the economic feasibility, the LCC analysis was performed as well. To estimate the economic advantages of an energy retrofitting project over its lifetime, LCC is a useful and comprehensive method [55]. The LCC can be calculated using equations (6) and (7) [56]:

$$
\begin{aligned}
& \text { LCC }=I C+\operatorname{USPW}\left(N, r_{d}\right) \times E C \quad(6) \\
& \text { USPW }\left(N, r_{d}\right)=\left[1-\left(1+r_{d}\right)^{-N}\right] \div r_{d} \quad(7)
\end{aligned}
$$

Where,

LCC the life cycle cost (\$)

IC initial cost for implementing all design and operating features for both building envelope and HVAC system (\$)

USPW ( $N, \mathrm{rd}$ ) Uniform series present worth factor which converts future recurrent expenses to present costs (Year)

$\begin{array}{ll}r_{d} & \text { Annual discount rate (\%) } \\ \mathrm{N} & \text { Lifetime (Year) } \\ \mathrm{EC} & \text { Annual energy cost required to }\end{array}$ maintain building indoor comfort for the selected design and operating features (\$)
To uniform all costs in a single currency in this study, we converted USD (\$) to Iranian Rials (IRR) with an exchange rate of $1 \$=250,000$ IRR in the LCC calculations. Table 12 presents the LCC in two different modes; $A$ and $B$; where energy cost (EC) is calculated with and without subsidy, respectively. For Both modes, the initial cost (IC) is 15.22 Billion IRR, The lifetime $(N)$ is assumed to be 20 years, and the discount rate $\left(r_{d}\right)$ is set to be $20 \%, 10 \%$, and $5 \%$. According to this table, $L C C$ ranges from 18.36 Billion IRR to 16 Billion IRR for mode A and from 38 Billion IRR to 20.93 Billion IRR for mode $B$. It is clear that only with the annual discount rate of $5 \%$, the minimum LCC is achieved for both modes. Therefore, the role of annual discount rate is vital for cost-effectiveness of such projects. The current annual discount rate in Iran is almost $20 \%$, which should be reduced by $15 \%$.

Table 12 LCC calculations

\begin{tabular}{cccccccccccc}
\hline $\begin{array}{c}\text { Subsidized } \\
\text { Energy } \\
\begin{array}{c}\text { Cost ( } \\
\text { Billion IRR) }\end{array}\end{array}$ & $\begin{array}{c}\text { IC } \\
\text { (Billion } \\
\text { IRR) }\end{array}$ & $\begin{array}{c}\text { A } \\
\text { (Year) }\end{array}$ & rd (\%) & $\begin{array}{c}\text { USPW } \\
\text { (Year) }\end{array}$ & $\begin{array}{c}\text { LCC } \\
\text { (Billion } \\
\text { IRR) }\end{array}$ & $\begin{array}{c}\text { Unsubsidi } \\
\text { zed } \\
\text { Energy } \\
\text { Cost } \\
\text { (Billion } \\
\text { IRR) }\end{array}$ & $\begin{array}{c}\text { IC (Billion } \\
\text { IRR) }\end{array}$ & $\begin{array}{c}\text { N } \\
\text { (Year) }\end{array}$ & $\begin{array}{c}r_{d} \\
\text { (\%) }\end{array}$ & $\begin{array}{c}\text { USPW } \\
\text { (Year) }\end{array}$ & $\begin{array}{c}\text { LCC } \\
\text { (Billion } \\
\text { IRR) }\end{array}$ \\
\hline $\mathbf{0 . 0 6 3}$ & 15.22 & 20 & 20 & 49.84 & 18.36 & 0.457 & 15.22 & 20 & 20 & 49.84 & 38 \\
\hline $\mathbf{0 . 0 6 3}$ & 15.22 & 20 & 10 & 24.92 & 16.79 & 0.457 & 15.22 & 20 & 10 & 24.92 & 26.63 \\
\hline $\mathbf{0 . 0 6 3}$ & 15.22 & 20 & 5 & 12.46 & 16 & 0.457 & 15.22 & 20 & 5 & 12.46 & 20.93 \\
\hline
\end{tabular}


In the final part of this section, the $\mathrm{CO}_{2}$ emission of LESM and NZEM is compared as shown in Figures 28. The annual $\mathrm{CO}_{2}$ emission has decreased from 43.2 Ton in LESM to 11.7 Ton in NZEM, suggesting a $73 \%$ reduction in annual $\mathrm{CO}_{2}$ emission. This is significant since NZEM can prevent emitting 31.5 tons and 945 tons of $\mathrm{CO}_{2}$ annually and in the lifetime of the building (30 years), respectively.

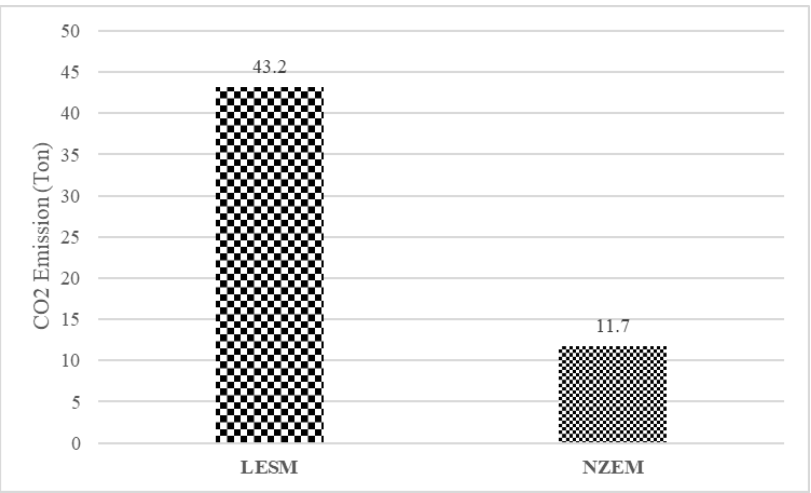

Figure 28 Annual $\mathrm{CO}_{2}$ emission

\subsection{CONCLUSION}

High energy use intensity and the urgent need to prevent local and regional climate change in southern Iran call for a suitable alternative to fossil fuels. The techno-economic and environmental feasibility of using active and passive solutions to optimize energy consumption along with the use of a PV system to balance the electricity demands of residential buildings in southern Iran were investigated in this study. To this end, a low-energy model of a multi-family residential building in Bushehr was selected as the dominant typology. Using active solutions, passive solutions, and energy-efficient home appliances, the annual electricity consumption of this model was reduced as much as possible. Then the annual electricity demand of this model was balanced using a grid-connected PV system. The findings revealed that the active and passive solutions of this study significantly decrease the EUI of dwellings in the South-West region of Iran and improve internal thermal comfort. The generated electricity of PV systems with the capacity of 29-30 KW in apartments with a total area of less than $1200 \mathrm{~m}^{2}$ in this region can balance the annual electricity demand. This system can export its surplus electricity to the grid which means achieving a plus energy building is quite possible. Therefore, achieving low carbon buildings, neighborhoods, and cities can be possible using the solutions of this study in the early stage design of new buildings and energy retrofitting of existing dwellings, and this region can contribute to mitigation and adaption to climate change. Although it has been shown that achieving the technical objectives of this study in NZEBs design in Southern Iran is quite feasible, due to the subsidized electricity, the current electricity export rate to the grid, the long payback period, and high rate of interest, investment in these projects will not be justified. To shorten the payback period to less than 6 years and to make such a project cost-effective, an electricity export rate was proposed which could be a part of incentive programs that government should initiate to enhance the application of solar energy in residential buildings in this part of Iran. Besides, energy subsidy must be eliminated by the government, and the annual discount rate should be reduced to achieve the minimum LCC. In future studies, the performance of such systems can be evaluated under future climate scenarios.

\section{Acknowledgment}

This research received no specific grant from any funding agency in the public, commercial, or not-forprofit sectors.

\section{References}

[1] IEA. Final Energy Consumption in Industry by Scenario, 1990-2040. 2019 6/17/2021; Available from: https://www.iea.org/data-and-statistics/charts/finalenergy-consumption-in-industry-by-scenario-1990-2040.

[2] Ng, P. K. and N. Mithraratne, 2014. Lifetime Performance of Semi-transparent Building-Integrated Photovoltaic (BIPV) Glazing Systems in the Tropics. Renewable and Sustainable Energy Reviews. 31: 736-745.

[3] UN. 2009. World Population Prospects. New York.

[4] Eshraghi, J., et al. 2014. A Comprehensive Feasibility Study of Applying Solar Energy to Design a Zero Energy Building for a Typical Home in Tehran. Energy \& Buildings. 72: 329339.

[5] Brahmand Zadeh, D. R .G., Z. 2014. Investigating the Trend of Changes in Power Consumption in Different Sectors During the Period from 2001 to 2012. Srtc-amar. 2: 29-33.

[6] Deng, S., et al. 2011. Energy Supply Concepts for Zero Energy Residential Buildings in Humid and Dry Climate. Energy Conversion and Management. 52(6): 2455-2460.

[7] Torcellini, P. and D. Crawley. 2006. Understanding ZeroEnergy Buildings. Ashrae Journal. 48: 62-69.

[8] Cao, X., X. Dai, and J. Liu. 2016. Building Energyconsumption Status Worldwide and the State-of-the-Art Technologies for Zero-energy Buildings During the Past Decade. Energy \& Buildings. 128: 198-213.

[9] Feng, W., et al. 2019. A Review of Net Zero Energy Buildings in Hot and Humid Climates: Experience Learned from 34 Case Study Buildings. Renewable and Sustainable Energy Reviews. 114.

[10] Liu, Z., et al. 2019. Review of Energy Conservation Technologies for Fresh Air Supply in Zero Energy Buildings. Applied Thermal Engineering. 148: 544-556.

[11] LU, Y., S. Wang, and K. Shan. 2015. Design Optimization and Optimal Control of Grid-connected and Standalone Nearly/Net Zero Energy Buildings. Applied Energy. 155: 463-477.

[12] Rabani, M., H. B. Madessa, and N. Nord. 2017. A State-ofart Review of Retrofit Interventions in Buildings Towards Nearly Zero Energy Level. Energy Procedia. 134(2017): 317326.

[13] Eley, C. 2017. Feasibility of ZNE by Building Type and Climate. ASHRAE Journal. 59(7): 32-37.

[14] Liu, C., et al. 2019. Energy Balance Evaluation and Optimization of Photovoltaic Systems for Zero Energy 
Residential Buildings in Different Climate Zones of China. Journal of Cleaner Production. 235: 1202-1215.

[15] Schuetze, T. 2015. Zero Emission Buildings in Korea-History, Status Quo, and Future Prospects. Sustainability. 7(3): 27452767.

[16] Tian, Z. et al. 2015. Investigations of Nearly (net) Zero Energy Residential Buildings in Beijing. Procedia Engineering. 121: 1051-1057.

[17] Wu, W. and H. M. 2018. Skye, Net-zero Nation: HVAC and PV Systems for Residential Net-zero Energy Buildings across the United States. Energy Conversion and Management. 177: 605-628.

[18] Xing, R., et al. 2018. Achieving Zero Emission in China's Urban Building Sector: Opportunities and Barriers. Current Opinion in Environmental Sustainability 30: 115-122.

[19] Abugrain, M. and H. Alibaba, 2017. Optimizing Existing Multistory Building Designs towards Net-Zero Energy. Sustainability. 9(3): 399 .

[20] Ascione, F., et al. 2016. Concept, Design and Energy Performance of a Net Zero-Energy Building in Mediterranean Climate. Procedia Engineering. 169: 26-37.

[21] Barbolini, F., P. Cappellacci, and L. Guardigli. 2017. A Design Strategy to Reach nZEB Standards Integrating Energy Efficiency Measures and Passive Energy Use. Energy Procedia. 111 (2017): 205-214.

[22] Diab, F., et al. 2015. An Environmentally-Friendly Tourist Village in Egypt Based on a Hybrid Renewable Energy System--Part Two: A Net Zero Energy Tourist Village. Energies. 8(7): 6945-6961.

[23] Ferrante, A. 2012. Zero- and Low-energy Housing for the Mediterranean Climate. Advances in Building Energy Research. 6(1): 81-118.

[24] Guillen-Lambea, S., B. Rodriguez-Soria, and J. Marin, 2017. Comfort Settings and Energy Demand for Residential nZEB in Warm Climates. Applied Energy. 202: 471-486.

[25] Abd-Ur-Rehman, H. M., et al. 2018. The Potential of Energy Savings and the Prospects of Cleaner Energy Production by Solar Energy Integration in the Residential Buildings of Saudi Arabia. Journal of Cleaner Production. 183: 11221130.

[26] Attia, S. and S. Carlucci. 2015. Impact of Different Thermal Comfort Models on Zero Energy Residential Buildings in Hot Climate. Energy \& Buildings. 102(C): 117-128.

[27] Boonyaputthipong, C. 2019. Building Envelope Renovation for Net Zero Energy Building in Hot Humid Climatex. IOP Conference Series: Earcth and Environmental Science. IOP publishing: Osaka, Japan.

[28] Hoque, S. and N. labal. 2015. Building to Net Zero in the Developing World. Buildings. 5(1): 56-68.

[29] Hu, M. 2019. Cost-effective Options for the Renovation of an Existing Education Building toward the Nearly Net-Zero Energy Goal-Life-Cycle Cost Analysis. Sustainability. 11 (8).

[30] Klingenberg, K., M. Kernagis, and M. Knezovich. 2016. Zero Energy and Carbon Buildings based on Climate-specific Passive Building Standards for North America. Journal of Building Physics. 39(6): 503-521.

[31] Kurdi, Y., et al. 2016. On the Performance of a Net Zero Energy House: A Case Study of the GridStar House in the Navy Yard, Philadelphia. Construction Research Congress 2016, J. Perdomo-Rivera, et al., Editors. Reston, VA: American Society of Civil Engineers: Reston, VA. 12131222

[32] Kwan, Y. and L. Guanz. 2015. Design a Zero Energy House in Brisbane, Australia. Procedia Engineering. 121: 604-611.

[33] Lou, S., et al. 2017. Towards Zero Energy School Building Designs in Hong Kong. Energy Procedia. 105(2017): 182187.

[34] Lu, Y., et al. 2017. Robust Optimal Design of Renewable Energy System in Nearly/Net Zero Energy Buildings Under Uncertainties. Applied Energy. $187(\mathrm{C}): 62-71$

[35] Ng, T. S. K., et al. 2016. Design and Commission a ZeroCarbon Building for Hot and Humid Climate. International Journal of Low-Carbon Technologies. 11 (2): 222-234.
[36] Russell, S. R. 2012. Hybrid Zero Energy Houses (zeh) for Florida's Hot, Humid Climate. International Journal of Design and Nature and Ecodynamics. 7(1): 93-108.

[37] Shin, M., et al. 2019. Evaluation of the Energy Performance of a Net Zero Energy Building in a Hot and Humid Climate. Energy \& Buildings. 204.

[38] Sudhakar, K., M. Winderl, and S. S. Priya. 2019. Net-Zero Building Designs in Hot and Humid Climates: A State-OfArt. Case Studies in Thermal Engineering. 13: 100400.

[39] To, C., J. Li, and M. Kam. 2017. Towards Zero Carbon in a Hot and Humid Subtropical Climate. Procedia Engineering. 180(2017): 413-422.

[40] Rezaee, R., R. Vakilinezhad, and J. Haymaker. 2021. Parametric Framework for a Feasibility Study of ZeroEnergy Residential Buildings for the Design Stage. Journal of Building Engineering. 35: 101960.

[41] Mahdavi Adeli, M., S. Farahat, and F. Sarhaddi. 2020. Optimization of Energy Consumption in Net-Zero Energy Buildings with Increasing Thermal Comfort of Occupants. International Journal of Photoenergy. 2020: 9682428.

[42] Vaghefpour, H. and K. Zabeh. 2012. Zero Energy Building in Iran. Energy Procedia. 18(C): 652-658.

[43] Shaddel, M. and M. Shokouhian. 2014. Feasibility of Solar Thermal Collectors Usage in Dwelling Apartments in Mashhad, The Second Megacity of Iran. Renewable and Sustainable Energy Reviews. 39: 1200-1207.

[44] Negar, A. and S. Bahram. 2018. Study of Effective Factors in the Design of Zero Energy Buildings in Arid Climate (Case of Isfahan City). Ukrainian Journal of Ecology. 8(1): 211-221.

[45] Solar Resource Map-Photovoltaic Power Potential- Islamic republic of Iran. 4/25/2020]; Available from: https://solargis.com/maps-and-gis-data/download/iran.

[46] Mohammadi, A. and J. A. Daraio. 2020. Improving the Energy Efficiency of Existing Residential Buildings by Applying Passive and Cost-Effective Solutions in the Hot and Humid Region of Iran. Space Ontology International Journal. 9(4): 77-96.

[47] Aldossary, N., Y. Rezgui, and A. Kwan. 2017. Establishing Domestic Low Energy Consumption Reference Levels for Saudi Arabia and the Wider Middle Eastern Region. Sustainable Cities and Society. 5-276.

[48] Christensen, C., et al. 2006. Cold-Climate Case Study for Affordable Zero Energy Homes: Preprint. United States. Department of Energy.

[49] Karthikeyan, V., et al. 2017. Grid-Connected and Off-Grid Solar Photovoltaic System. Smart Energy Grid Design for Island Countries: Challenges and Opportunities. Springer International Publishing. 125-157.

[50] SolarWorld. 2018. Sunmodule Plus SW 290/300 Mono Data Sheet.

[51] Al-Najideen, M. I. and S. S. Alrwashdeh. 2017. Design of a Solar Photovoltaic System to Cover the Electricity Demand for the Faculty of Engineering- Mu'tah University in Jordan. Resource-Efficient Technologies. 3(4): 440-445.

[52] Duffie, J. A. and W. A. Beckman. 2013. Design of Photovoltaic Systems. Solar Engineering of Thermal Processes. John Wiley \& Sons: USA. 45-773.

[53] d'Ambrosio Alfano, F. R., B. W. Olesen, and B. I. Palella. 2017. Povl Ole Fanger's Impact Ten Years Later. Energy and Buildings. 152: 243-249.

[54] Institute, P. H. 2016. Criteria for the Passive House, EnerPHit and PHI Low Energy Building Standard. Passive House Institute: Germany

[55] Al-Saeed, Y. W. and A. Ahmed. 2018. Evaluating Design Strategies for Nearly Zero Energy Buildings in the Middle East and North Africa Regions. Designs. 2(4).

[56] Krarti, M. and P. Ihm. 2016. Evaluation of Net-zero Energy Residential Buildings in the MENA Region. Sustainable Cities and Society. 22: 116-125.

[57] Harkouss, F., F. Fardoun, and P. H. Biwole. 2018. MultiObjective Optimization Methodology for Net Zero Energy Buildings. Journal of Building Engineering. 16: 57-71. 